\title{
Evidence for a major missing source in the global chloromethane budget from stable carbon isotopes
}

\author{
Enno Bahlmann ${ }^{1,2}$, Frank Keppler ${ }^{3,4,5}$, Julian Wittmer ${ }^{6,7}$, Markus Greule ${ }^{3,4}$, Heinz Friedrich Schöler ${ }^{3}$, \\ Richard Seifert $^{1}$, and Cornelius Zetzsch ${ }^{5,6}$ \\ ${ }^{1}$ Institute of Geology, University Hamburg, Bundesstrasse 55, 20146 Hamburg, Germany \\ ${ }^{2}$ Leibniz Centre for Tropical Marine Research, Fahrenheitstraße 6, 28359 Bremen, Germany \\ ${ }^{3}$ Institute of Earth Sciences, Heidelberg University, Im Neuenheimer Feld 234-236, 69120 Heidelberg, Germany \\ ${ }^{4}$ Heidelberg Center for the Environment (HCE), Heidelberg University, 69120 Heidelberg, Germany \\ ${ }^{5}$ Max-Planck-Institute for Chemistry, Hahn-Meitner-Weg 1, 55128 Mainz, Germany \\ ${ }^{6}$ Atmospheric Chemistry Research Unit, BayCEER, University of Bayreuth, \\ Dr Hans-Frisch Strasse 1-3, 95448 Bayreuth, Germany \\ ${ }^{7}$ Agilent Technologies Sales \& Services GmbH \& Co. KG, Hewlett-Packard-Str. 8, 76337 Waldbronn, Germany
}

Correspondence: Enno Bahlmann (enno.bahlmann@ leibniz-zmt.de)

Received: 17 August 2018 - Discussion started: 11 September 201

Revised: 17 January 2019 - Accepted: 18 January 2019 - Published: 8 February 2019

\begin{abstract}
Chloromethane $\left(\mathrm{CH}_{3} \mathrm{Cl}\right)$ is the most important natural input of reactive chlorine to the stratosphere, contributing about $16 \%$ to stratospheric ozone depletion. Due to the phase-out of anthropogenic emissions of chlorofluorocarbons, $\mathrm{CH}_{3} \mathrm{Cl}$ will largely control future levels of stratospheric chlorine.

The tropical rainforest is commonly assumed to be the strongest single $\mathrm{CH}_{3} \mathrm{Cl}$ source, contributing over half of the global annual emissions of about 4000 to $5000 \mathrm{Gg}$ $\left(1 \mathrm{Gg}=10^{9} \mathrm{~g}\right)$. This source shows a characteristic carbon isotope fingerprint, making isotopic investigations a promising tool for improving its atmospheric budget. Applying carbon isotopes to better constrain the atmospheric budget of $\mathrm{CH}_{3} \mathrm{Cl}$ requires sound information on the kinetic isotope effects for the main sink processes: the reaction with $\mathrm{OH}$ and $\mathrm{Cl}$ in the troposphere. We conducted photochemical $\mathrm{CH}_{3} \mathrm{Cl}$ degradation experiments in a $3500 \mathrm{dm}^{3}$ smog chamber to determine the carbon isotope effect $\left(\varepsilon=k^{13} \mathrm{C} / k^{12} \mathrm{C}-1\right)$ for the reaction of $\mathrm{CH}_{3} \mathrm{Cl}$ with $\mathrm{OH}$ and $\mathrm{Cl}$. For the reaction of $\mathrm{CH}_{3} \mathrm{Cl}$ with $\mathrm{OH}$, we determined an $\varepsilon$ value of $(-11.2 \pm 0.8) \%$ o $(n=3)$ and for the reaction with $\mathrm{Cl}$ we found an $\varepsilon$ value of $(-10.2 \pm 0.5) \% o(n=1)$, which is 5 to 6 times smaller than previously reported. Our smaller isotope effects are strongly supported by the lack of any significant seasonal covariation in previously reported tropospheric $\delta^{13} \mathrm{C}\left(\mathrm{CH}_{3} \mathrm{Cl}\right)$ values
\end{abstract}

with the $\mathrm{OH}$-driven seasonal cycle in tropospheric mixing ratios.

Applying these new values for the carbon isotope effect to the global $\mathrm{CH}_{3} \mathrm{Cl}$ budget using a simple two hemispheric box model, we derive a tropical rainforest $\mathrm{CH}_{3} \mathrm{Cl}$ source of $(670 \pm 200) \mathrm{Gg} \mathrm{a}^{-1}$, which is considerably smaller than previous estimates. A revision of previous bottom-up estimates, using above-ground biomass instead of rainforest area, strongly supports this lower estimate. Finally, our results suggest a large unknown $\mathrm{CH}_{3} \mathrm{Cl}$ source of $(1530 \pm$ 200) $\mathrm{Gg} \mathrm{a}^{-1}$.

\section{Introduction}

In the mid-1990s, the recognition that the known $\mathrm{CH}_{3} \mathrm{Cl}$ sources, mainly biomass burning and marine emissions, are insufficient to balance the known atmospheric sinks (Butler, 2000). This motivated intense research on potential terrestrial sources. Today, it is common thinking that large emissions from tropical rainforests (Monzka et al., 2010; Xiao et al., 2010; Carpenter et al., 2014) can close this gap. Several model studies revealed a strong tropical $\mathrm{CH}_{3} \mathrm{Cl}$ source in the range of $2000 \mathrm{Gg} \mathrm{a}^{-1}$ (Xiao et al., 2010; Yoshida et al., 2006; Lee Taylor et al., 2001). Particular support for a strong 
tropical rainforest source arose from observations of elevated $\mathrm{CH}_{3} \mathrm{Cl}$ concentrations in the vicinity of tropical rainforests (Yokouchi et al., 2000), greenhouse experiments (Yokouchi et al., 2002), several field measurements in tropical rainforests (Saito et al., 2008, 2013; Gebhardt et al., 2008; Blei et al., 2010) and from carbon stable isotope mass balances (Keppler et al., 2005; Saito and Yokouchi, 2008). The majority of $\mathrm{CH}_{3} \mathrm{Cl}$ in tropical rainforests $\left((2000 \pm 600) \mathrm{Gg} \mathrm{a}^{-1}\right)$ is thought to originate from higher plants (Monzka et al., 2010; Xiao et al., 2010; Yokouchi et al., 2000; Saito and Yokouchi, 2008). A minor fraction of about $150 \mathrm{Gg} \mathrm{a}^{-1}$ may be emitted from wood rotting fungi (Monzka et al., 2010; Xiao et al., 2010; Carpenter et al., 2014). Further emissions from senescent leaf litter (Keppler et al., 2005) may substantially contribute to this source, but this has not yet been confirmed in field studies (Blei et al., 2010). On a global scale, biomass burning (400 to $1100 \mathrm{Gg} \mathrm{a}^{-1}$ ) and surface ocean net emissions (140 to $640 \mathrm{Gg} \mathrm{a}^{-1}$ ) are further important sources (Monzka et al., 2010; Xiao et al., 2010; Carpenter et al., 2014). Chloromethane from higher plants has an average stable isotope signature $\left({ }^{13} \mathrm{C} /{ }^{12} \mathrm{C}\right.$ ratio, $\delta^{13} \mathrm{C}$ value $)$ of $(-83 \pm 15) \%$ (Saito et al., 2008; Saito and Yokouchi, 2008). Compared to the other known sources with $\delta^{13} \mathrm{C}$ values in the range $-36 \%$ to $-62 \%$ (Keppler et al., 2005; Saito and Yokouchi, 2008), the tropical rainforest source is exceptionally depleted in ${ }^{13} \mathrm{C}$, making stable isotope approaches particularly useful for better constraining $\mathrm{CH}_{3} \mathrm{Cl}$ flux estimates.

The isotopic composition of tropospheric $\mathrm{CH}_{3} \mathrm{Cl}$ links the isotopic source signatures to the kinetic isotope effects (KIEs) of the sinks. The primary $\mathrm{CH}_{3} \mathrm{Cl}$ sink is its oxidation in the troposphere by $\mathrm{OH}$ and $\mathrm{Cl}$, accounting for about $80 \%$ of total losses (Monzka et al., 2010; Xiao et al., 2010; Carpenter et al., 2014). Further sinks comprise soil uptake and loss to the stratosphere (Monzka et al., 2010; Xiao et al., 2010; Carpenter et al., 2014). An accurate determination of the KIEs of the main tropospheric sink reactions $\left(\mathrm{CH}_{3} \mathrm{Cl}+\mathrm{OH}, \mathrm{CH}_{3} \mathrm{Cl}+\mathrm{Cl}\right)$ is crucial for constraining the tropical rainforest source from an isotopic perspective. A previous study (Gola et al., 2005) revealed large $\varepsilon$ values of $(-59 \pm 8) \%$ and $(-70 \pm 10) \%$ o for the reaction of $\mathrm{CH}_{3} \mathrm{Cl}$ with $\mathrm{OH}$ and $\mathrm{Cl}$, respectively, which supported the hypothesis of large emissions from tropical rainforests (Keppler et al., 2005; Saito and Yokouchi, 2008). In particular, the $\varepsilon$ value for the reaction with $\mathrm{OH}$ is much larger in comparison to previously reported $\varepsilon$ values for the reaction of $\mathrm{OH}$ with methane (Saueressig et al., 2001) and other hydrocarbons (Rudolph et al., 2000; Anderson et al., 2004). We thus performed photochemical degradation experiments of $\mathrm{CH}_{3} \mathrm{Cl}$ in a $3500 \mathrm{dm}^{3}$ Teflon smog chamber using established radical generation schemes (see method section for details) to reassess the KIEs for the reaction of $\mathrm{CH}_{3} \mathrm{Cl}$ with $\mathrm{OH}$ and $\mathrm{Cl}$. For validation purposes, we further determined the known KIEs for the same reactions of methane $\left(\mathrm{CH}_{4}\right)$.

In the next step, we used the seasonal variations in the mixing ratios (Prinn et al., 2000) and isotopic composition
(Thompson et al., 2002; Redeker et al., 2007) of tropospheric $\mathrm{CH}_{3} \mathrm{Cl}$ to further assess the reliability of the obtained KIEs. This was done with a simple two-box model, dividing the atmosphere into a Northern and a Southern Hemisphere and using a simplified emission scheme. The same model was then used to constrain the tropical rainforest source from an isotopic perspective. We finally improved previous bottomup estimates of the tropical rainforest source using carbon density maps of the tropical rainforest instead of coverage area.

\section{The kinetic isotope effect $(\varepsilon)$ for the reaction of $\mathrm{CH}_{3} \mathrm{Cl}$ with $\mathrm{OH}$ and $\mathrm{Cl}$}

\subsection{Materials and methods}

\subsubsection{Smog chamber}

The smog chamber set-up and the experimental conditions are the same as recently described in Keppler et al. (2018). The samples for the carbon isotope analysis were taken from the same experiments described therein. Briefly, the isotope fractionation experiments were performed in a $(3500 \pm$ 100) $\mathrm{dm}^{3}$ Teflon smog chamber. The chamber was continuously flushed with purified, hydrocarbon-free zero air (zeroair generator, cmc instruments, $<1 \mathrm{nmol} \mathrm{mol}^{-1}$ of $\mathrm{O}_{3},<$ $500 \mathrm{pmol} \mathrm{mol}^{-1} \mathrm{NO}_{x},<100 \mathrm{nmol} \mathrm{mol}^{-1}$ of $\mathrm{CH}_{4}$ ) at a rate of $0.6-4 \mathrm{dm}^{3} \mathrm{~min}^{-1}$ to maintain a slight overpressure of $0.5-$ $1 \mathrm{~Pa}$ logged with a differential pressure sensor (Kalinsky Elektronik DS1). A Teflon fan inside the chamber ensured constant mixing throughout the experiments. $\mathrm{NO}$ and $\mathrm{NO}_{x}$ were monitored on a routine basis with an Eco Physics, CLD 88p chemiluminiscence analyser coupled with an Eco Physics photolytic converter, PLC 860. Ozone was monitored by a chemiluminescence analyser (UPK 8001). Initial $\mathrm{CH}_{3} \mathrm{Cl}$ mixing ratios were between 5 and $14 \mu \mathrm{mol} \mathrm{mol}{ }^{-1}$. Perfluorohexane (PFH) was used as an internal standard with initial mixing ratios of $(25 \pm 3) \mu \mathrm{mol} \mathrm{mol}^{-1}$ to correct the resulting concentrations for dilution. The mixing ratios of $\mathrm{CH}_{3} \mathrm{Cl}$ and $\mathrm{PFH}$ were monitored by GC-MS (Agilent Technologies, Palo Alto, CA) with a time resolution of 15 minutes throughout the experiments. The stability of the instrument was regularly checked using a gaseous standard $\left(5 \mathrm{~mL}\right.$ of $100 \mu \mathrm{mol} \mathrm{mol}^{-1} \mathrm{CH}_{3} \mathrm{Cl}$ in $\mathrm{N}_{2}$ ). Mixing ratios of methane and $\mathrm{CO}_{2}$, used as an internal standard in the methane degradation experiments, were measured with a Picarro G221i cavity ring-down spectrometer. Prior to the experiments, the instrument was calibrated with pressurized ambient air from a tank obtained from the Max-PlanckInstitute for Biogeochemistry in Jena, Germany $\left(\mathrm{CO}_{2}\right.$ mixing ratio of $(394.6 \pm 0.5) \mu \mathrm{mol} \mathrm{mol}^{-1}$, methane mixing of $\left.(1.752 \pm 0.002) \mu \mathrm{mol} \mathrm{mol}{ }^{-1}\right)$. OH radicals were generated via the photolysis of ozone (about $2000 \mathrm{nmol} \mathrm{mol}^{-1}$ for $\mathrm{CH}_{3} \mathrm{Cl}$ and about $10000 \mathrm{nmol} \mathrm{mol}^{-1}$ for $\mathrm{CH}_{4}$ ) at $253.7 \mathrm{~nm}$ in the 
presence of water vapour (Relative humidity $=70 \%$ ). This is a well-established efficient method for $\mathrm{OH}$ radical generation (Cantrell et al., 1990; DeMore, 1993). In the $\mathrm{CH}_{3} \mathrm{Cl}+\mathrm{OH}$ experiments, initially $2000 \mathrm{mmol} \mathrm{mol}^{-1}$ of $\mathrm{H}_{2}$ was added for scavenging chlorine radicals originating from the photolysis or oxidation of formyl chloride $(\mathrm{HCOCl})$ occurring as an intermediary in the reaction cascade (Gola et al., 2005). To obtain an efficient $\mathrm{OH}$ formation, Philips TUV lamps $(1 \times 55 \mathrm{~W}$ for $\mathrm{CH}_{3} \mathrm{Cl}, 4 \times 55 \mathrm{~W}$ for $\mathrm{CH}_{4}$ ) were welded in Teflon film and mounted inside or around the smog chamber. Atomic chlorine $(\mathrm{Cl})$ was generated via photolysis of molecular chlorine $\left(\mathrm{Cl}_{2}\right)$ at a relative humidity of less than $1 \%$ by a solar simulator (Behnke et al., 1988) with an actinic flux comparable to the sun at midsummer in Germany and a photolysis frequency of $J=1.55 \times 10^{-3} \mathrm{~s}^{-1}$ for $\mathrm{Cl}_{2}$ (Buxmann et al., 2012). A more detailed description of the smog chamber setup is provided in the Supplement and has recently been published elsewhere (Wittmer et al., 2015; Keppler et al., 2018).

\subsubsection{Sampling and carbon isotope determination}

From each experiment 10 to 15 canister samples $\left(2 \mathrm{dm}^{3}\right.$ stainless steel, evacuated $<1.3 \times 10^{-3} \mathrm{~Pa}$ and baked out at $250{ }^{\circ} \mathrm{C}$ for $2 \mathrm{~h}$ ) and 10 to 15 adsorption tube samples were taken at regular time intervals for subsequent analysis of carbon isotope ratios. The adsorption tubes were made of stainless steel (1/4 inch outer diameter, 7 inch length) and filled with $77 \mathrm{mg}$ Carboxen $1016^{\circledR}, 215 \mathrm{mg}$ Carbopack X $569^{\circledR}, 80 \mathrm{mg}$ Carboxen ${ }^{\circledR} 1003$ and $9 \mathrm{mg}$ Tenax ${ }^{\circledR}$ TA in order of the sampling flow direction. The adsorption tube samples and one set of canister samples from the $\mathrm{CH}_{3} \mathrm{Cl}$ degradation experiments were analysed by 2D-GC-IRMS/MS at the University of Hamburg using the method of Bahlmann et al. (2011). This method has been shown to be free of interference from other compounds. The precision and reproducibility of the $\delta^{13} \mathrm{C}$ measurements based on standards were $\pm 0.6 \%$ o $(n=18)$ on the $1 \sigma$ level. In order to assure compliance with VPDB scale, a single-component standard of $\mathrm{CH}_{3} \mathrm{Cl}\left(100 \mu \mathrm{mol} \mathrm{mol}^{-1}\right.$ in nitrogen, Linde Germany) was calibrated against a certified $\mathrm{CO}_{2}$ reference standard (Air Liquide, Germany, $(-26.8 \pm 0.2) \%$ ) and a solid standard (NIST NBS 18, RM 8543) after offline combustion and analysis via a dual inlet (DI). The results from the DI $(n=6)$ were $(-37.2 \pm 0.1) \%$ o for $\mathrm{CH}_{3} \mathrm{Cl}$. The respective $\delta^{13} \mathrm{C}$ values from the GC-GC-IRMS, measured against the machine working gas (Air Liquide, Germany, $(-26.8 \pm 0.2) \%$ ) were $(-36.1 \pm 0.2) \%$, resulting in an offset (DI $-2 \mathrm{D}-\mathrm{GC}-\mathrm{IRMS})$ of $-1.1 \%$ ofor $\mathrm{CH}_{3} \mathrm{Cl}$.

The canister samples were analysed at the University of Heidelberg using a cryogenic pre-concentration system coupled to a GC-C-IRMS system, developed for $\delta^{2} \mathrm{H}$ measurements of $\mathrm{CH}_{3} \mathrm{Cl}$ (Greule et al., 2013). A combustion reactor filled with copper (II) oxide at $850^{\circ} \mathrm{C}$ was used to analyse $\delta^{13} \mathrm{C}$. The precision and reproducibility of these $\delta^{13} \mathrm{C}$ measurements based on a $\mathrm{CH}_{3} \mathrm{Cl}$ working standard were $\pm 0.47 \%$ o $(n=47)$ on the $1 \sigma$ level. The sampled $\mathrm{CH}_{3} \mathrm{Cl}$ amounts varied between 0.8 and $15 \mathrm{nmol}$. Both methods were linear over the whole range of sampled $\mathrm{CH}_{3} \mathrm{Cl}$ amounts. The $\delta^{13} \mathrm{C}$ values measured in both laboratories generally agreed within $\pm 1.3 \%$ on the $1 \sigma$ level. This range is somewhat larger than expected from error propagation and may result from small additional errors of scale adding to the uncertainty. For the purpose of this study no attempts were made to adjust the measured $\delta^{13} \mathrm{C}$ values. $\mathrm{CH}_{4}$ carbon isotope ratios were only analysed at the University of Heidelberg.

\subsubsection{Calculation of $\varepsilon$}

The carbon isotope ratios are reported in the $\delta$ notation relative to the VPDB scale (Vienna Pee Dee Belemnite), and the kinetic isotope effect (KIE, symbol $\varepsilon$ ) is reported in \%o. We applied an orthogonal regression model (Danzer et al., 1995) to derive the kinetic isotope effect for each experiment from the slope of the Rayleigh plot:

$\varepsilon \times \ln \left(f_{t}\right)=\ln \left(\frac{\delta^{13} \mathrm{C}_{t}+1}{\delta^{13} \mathrm{C}_{0}+1}\right)$,

with $\varepsilon$ being the kinetic isotope effect, $f_{t}$ being the residual $\mathrm{CH}_{3} \mathrm{Cl}$ fraction at time $t, \delta^{13} \mathrm{C}_{0}$ being the initial carbon isotope ratio of the substrate $\% o, \delta^{13} \mathrm{C}_{t}$ being the carbon isotope ratio of the substrate $\% o$ at time $t$. To account for the dilution from the airflow through the chamber, the residual fraction $\left(f_{t}\right)$ has been calculated from the mixing ratios of $\mathrm{CH}_{3} \mathrm{Cl}$ and the inert tracer, $\mathrm{PFH}$, as follows:

$f_{t}=\frac{\left[\mathrm{CH}_{3} \mathrm{Cl}_{t}\right] \times\left[\mathrm{PFH}_{0}\right]}{\left[\mathrm{CH}_{3} \mathrm{Cl}_{0}\right] \times\left[\mathrm{PFH}_{t}\right]}$.

Here, $\left[\mathrm{CH}_{3} \mathrm{Cl}\right]$ and $[\mathrm{PFH}]$ denote the respective concentrations, and the indices $t$ and 0 refer to time $t$ and zero. The uncertainty for $f_{t}$ ranged from $1.4 \%$ to $1.8 \%$ on the $1 \sigma$ level.

\subsection{Results of the $\mathrm{CH}_{3} \mathrm{Cl}$ degradation experiments}

In total, we performed six degradation experiments and two control experiments within this study. To perform the degradation experiments within a day, the experimental conditions were modified as indicated in Table 1. For the $\mathrm{OH}$ experiments in the presence of $\mathrm{CH}_{4}$, the light intensity was increased from 55 to $220 \mathrm{~W}$, and the steady-state ozone mixing ratios were increased from about $620 \mathrm{nmol} \mathrm{mol}^{-1}$ to about $3570 \mathrm{nmol} \mathrm{mol}^{-1}$. Under these experimental conditions, typically $70 \%$ to $80 \%$ of the initial $\mathrm{CH}_{3} \mathrm{Cl}$ and $\mathrm{CH}_{4}$ were degraded within 6 to $10 \mathrm{~h}$. A more detailed discussion of the experimental conditions with respect to the $\mathrm{OH}$ yields and degradation rates is provided in the Supplement. Further, the reader is referred to Keppler et al. (2018), who reported on the hydrogen isotope effects from these experiments.

Prior to each degradation experiment, we monitored the ratio of $\mathrm{CH}_{3} \mathrm{Cl}$ and perfluorohexane (PFH) for at least $2 \mathrm{~h}$ to assess potential side reactions and unwanted losses of $\mathrm{CH}_{3} \mathrm{Cl}$. 
Table 1. Experimental conditions of the degradation experiments with $\mathrm{OH}$. The $\mathrm{O}_{3}$ mixing ratios are average steady-state mixing ratios throughout the experiment, the $\mathrm{Cl}_{2}$ mixing ratios refer to the initial mixing ratios at the beginning of each photolysis sequence.

\begin{tabular}{|c|c|c|c|c|c|c|c|c|c|}
\hline \multirow[t]{2}{*}{ Experiment } & \multicolumn{2}{|c|}{ Reactant } & \multirow[t]{2}{*}{ Oxidant } & \multirow{2}{*}{$\begin{array}{r}\mathrm{O}_{3}, \mathrm{Cl}_{2} \\
\mu \mathrm{mol} \mathrm{mol}-1\end{array}$} & \multirow[t]{2}{*}{ Irradiation } & \multirow{2}{*}{$\begin{array}{r}\mathrm{H}_{2} \\
\mu \mathrm{mol} \mathrm{mol}\end{array}$} & \multirow{2}{*}{$\begin{array}{r}\text { Relative humidity } \\
\%\end{array}$} & \multirow{2}{*}{$\begin{array}{c}T \\
{ }^{\circ} \mathrm{C}\end{array}$} & \multirow{2}{*}{$\begin{array}{r}\mathrm{OH} \\
\mathrm{cm}^{-3}\end{array}$} \\
\hline & & $\mu \mathrm{mol} \mathrm{mol}-1$ & & & & & & & \\
\hline 1 and 2 & $\mathrm{CH}_{3} \mathrm{Cl}$ & 5,10 & $\mathrm{OH}$ & 0.62 & $1 \times 55 \mathrm{~W}, \lambda_{\max }=254 \mathrm{~nm}$ & 2000 & 65 & 20.7 & $2.9 \times 10^{9}$ \\
\hline 3 & $\mathrm{CH}_{3} \mathrm{Cl}$ & 0.13 & $\mathrm{OH}$ & 0.62 & $1 \times 55 \mathrm{~W}, \lambda_{\max }=254 \mathrm{~nm}$ & 2000 & $<1$ & 20.6 & $8.7 \times 10^{7}$ \\
\hline 4 & $\mathrm{CH}_{3} \mathrm{Cl}, \mathrm{CH}_{4}$ & 13,5 & $\mathrm{OH}$ & 3.7 & $4 \times 55 \mathrm{~W}, \lambda_{\max }=254 \mathrm{~nm}$ & 2000 & 65 & 20.4 & $1.6 \times 10^{10}$ \\
\hline 5 & $\mathrm{CH}_{4}$ & 5 & & 0 & $4 \times 55 \mathrm{~W}, \lambda_{\max }=254 \mathrm{~nm}$ & & 72 & 20.3 & \\
\hline 6 & $\mathrm{CH}_{4}$ & 6 & $\mathrm{OH}$ & 3.7 & $4 \times 55 \mathrm{~W}, \lambda_{\max }=254 \mathrm{~nm}$ & & 72 to 75 & 20.3 & $1.6 \times 10^{10}$ \\
\hline 7 & $\mathrm{CH}_{3} \mathrm{Cl}$ & 10 & $\mathrm{Cl}$ & 2 to 10 & $7 \times 1200 \mathrm{~W} 300-700 \mathrm{~nm}$ & & $<1$ & 20.7 & \\
\hline 8 & $\mathrm{CH}_{4}$ & 5 & $\mathrm{Cl}$ & 2 to 10 & $7 \times 1200 \mathrm{~W} 300-700 \mathrm{~nm}$ & & $<1$ & 20.5 & \\
\hline
\end{tabular}

For the experiment with chlorine, this was done under dark conditions in the presence of $10 \mu \mathrm{mol} \mathrm{mol}^{-1} \mathrm{Cl}_{2}$. For the $\mathrm{OH}$ experiments, this was either done in the absence of light or ozone. None of these tests revealed an indication of a measurable loss $(1.4 \%$ to $2.1 \%)$ of $\mathrm{CH}_{3} \mathrm{Cl}$ and thus for any biasing side effects or reactions. In the $\mathrm{CH}_{4}$ degradation experiments, $\mathrm{CO}_{2}$ was used as an internal standard to correct the $\mathrm{CH}_{4}$ mixing ratios for dilution. A control experiment over $9 \mathrm{~h}$, carried out with a dilution flow of $4 \mathrm{dm}^{3} \mathrm{~min}^{-1}$ of zero air, revealed a slope $(-0.00118 \pm 0.00001) \mathrm{min}^{-1}$ for $\mathrm{CH}_{4}$ loss and a slope of $(-0.00117 \pm 0.000007) \mathrm{min}^{-1}$ for the $\mathrm{CO}_{2}$ loss. This corresponds to a dilution flow of $(4.1 \pm 0.1) \mathrm{dm}^{3} \mathrm{~min}^{-1}$, which is in good agreement with the pre-set dilution flow (the major uncertainty in this calculation is the exact volume of the chamber). During this control experiment, the dilutioncorrected mixing ratio of $\mathrm{CH}_{4}$ changed by less than $0.2 \%$.

In our study, photolysis of ozone $\left(620 \mathrm{nmol} \mathrm{mol}^{-1}\right.$ steadystate mixing ratio) in the absence of water vapour (relative humidity $<1 \%$ ) but with $2000 \mu \mathrm{mol} \mathrm{mol}^{-1} \mathrm{H}_{2}$ (experiment 3) resulted in a $\mathrm{CH}_{3} \mathrm{Cl}$ degradation of less than $3 \%$ over $10 \mathrm{~h}$ and no measurable change in the isotopic composition of $\mathrm{CH}_{3} \mathrm{Cl}(-46.8 \%$ at the beginning and $-46.1 \%$ after $10 \mathrm{~h}$ ) because of the insufficient $\mathrm{OH}$ yield. The reaction rate constants of $\mathrm{O}\left({ }^{1} \mathrm{D}\right)$ with $\mathrm{H}_{2}$ and $\mathrm{H}_{2} \mathrm{O}$ at $298 \mathrm{~K}$ are $1.1 \times$ $10^{-10}$ and $2.2 \times 10^{-10} \mathrm{~cm}^{3} \mathrm{~s}^{-1}$, respectively (Burkholder et al., 2015). At a relative humidity of $70 \%$ (corresponding to $16000 \mu \mathrm{mol} \mathrm{mol}^{-1}$ ), the reaction with $\mathrm{H}_{2} \mathrm{O}$ is by far the main pathway along which $\mathrm{OH}$ forms (with the $\mathrm{H}_{2}$ pathway contributing less than $4 \%$ to the $\mathrm{OH}$ yield). This is consistent with the previous study, where ozone levels of $300 \mu \mathrm{mol} \mathrm{mol}^{-1}$ were required for a sufficient $\mathrm{OH}$ production from $\mathrm{H}_{2}$ (Gola et al., 2005; Sellevåg et al., 2006). For this experiment, the partial lifetime of $\mathrm{CH}_{3} \mathrm{Cl}$ with respect to $\mathrm{OH}$ can be estimated to be about $330 \mathrm{~h}$. Potential side reactions with $\mathrm{O}\left({ }^{1} \mathrm{D}\right)$ were not explicitly investigated in our study but because of the reduced $\mathrm{OH}$ yield, this experiment allows potential losses of $\mathrm{CH}_{3} \mathrm{Cl}$ to be constrained due to the reaction with $\mathrm{O}\left({ }^{1} \mathrm{D}\right)$. In experiment 4 , where both $\mathrm{CH}_{3} \mathrm{Cl}$ and $\mathrm{CH}_{4}$ were present, the ratio of the measured rate constants for the reaction of $\mathrm{CH}_{3} \mathrm{Cl}$ and $\mathrm{CH}_{4}$ with $\mathrm{OH}$ was 5.8. This ratio agrees well with that of the recommended rate constants of 5.6 at $298 \mathrm{~K}\left(6.3 \times 10^{-15} \mathrm{~cm}^{3} \mathrm{~s}^{-1}\right.$ for $\mathrm{CH}_{4}$ and, $3.5 \times 10^{-14} \mathrm{~cm}^{3} \mathrm{~s}^{-1}$ for $\mathrm{CH}_{3} \mathrm{Cl}$ at $298 \mathrm{~K}$; Burkholder et al., 2015).

The change in stable carbon isotope $\delta$ values of $\mathrm{CH}_{3} \mathrm{Cl}$ $\left({ }^{13} \mathrm{C}\left(\mathrm{CH}_{3} \mathrm{Cl}\right)\right)$ with the extent of the reaction and the corresponding Rayleigh plots of the $\mathrm{CH}_{3} \mathrm{Cl}$ degradation experiments are shown in Fig. 1. The respective $\varepsilon$ values, derived from the slope of the Rayleigh plot, are summarized in Table 2. For the reaction of $\mathrm{CH}_{3} \mathrm{Cl}$ with $\mathrm{OH}$, we determined an $\varepsilon$ value of $(-11.2 \pm 0.8) \% o(n=3)$ and for the reaction with $\mathrm{Cl}$ we found an $\varepsilon$ value of $(-10.2 \pm 0.5) \%_{o}(n=1)$. The results from both laboratories generally agreed within $\pm 1.5 \%$ o $(1 \sigma)$ and showed no systematic difference. Variations in the initial mixing ratios (5 to $13 \mu \mathrm{mol} \mathrm{mol}^{-1}$ ) and isotopic composition $((-47.0 \pm 0.5) \% o$ and $(-40.3 \pm 0.5) \%$ o $)$ of $\mathrm{CH}_{3} \mathrm{Cl}$ in the $\mathrm{OH}$ experiments had no significant effect on the determination of the isotope effects. Furthermore, the increase in the light intensity and ozone mixing ratios in experiment 4 had no effect on the isotope effects.

The $\varepsilon$ values for the reaction of $\mathrm{CH}_{4}$ with $\mathrm{OH}$ and $\mathrm{Cl}$, determined for validation purposes, agreed reasonably well with the previously published KIEs (Saueressig et al., 1995, 2001; Tyler et al., 2000; Feilberg et al., 2005). For the reaction of $\mathrm{CH}_{4}$ with $\mathrm{OH}$, we found an $\varepsilon$ value of $-4.7 \%$, which is at the upper end in terms of absolute magnitude of previously reported fractionation factors, and for the reaction with $\mathrm{Cl}$ we found an $\varepsilon$ value of $-59 \%$, which is more at the lower end of previously measured KIEs (Table 3). Prior to the $\mathrm{CH}_{4}$ degradation experiment with $\mathrm{OH}$, we performed a control experiment (experiment 5 in Table 1) that revealed no $\mathrm{CH}_{4}$ loss over $10 \mathrm{~h}$. With this, we can exclude any interference from reactive chlorine during the $\mathrm{CH}_{4}-\mathrm{OH}$ experiment. The larger isotope effect for the reaction with $\mathrm{OH}$ found here might result from the reaction of $\mathrm{CH}_{4}$ with $\mathrm{O}\left({ }^{1} \mathrm{D}\right)$. Cantrell et al. (1990), who also used UV-photolysis in the presence of water as an $\mathrm{OH}$ source, reported an even higher $\varepsilon$ value of $(-5.4 \pm 0.9) \%$ and estimated that the reaction of $\mathrm{CH}_{4}$ with $\mathrm{O}\left({ }^{1} \mathrm{D}\right)$ (showing an $\varepsilon$ value of $-13 \%$; Saueressig et al., 2001) may have contributed about $3 \%$ to the overall degradation. Saueressig et al. (2001) reported an $\varepsilon$ value of $-3.9 \%$ o for the reaction of $\mathrm{CH}_{4}$ with $\mathrm{OH}$. With respect to this value, a 

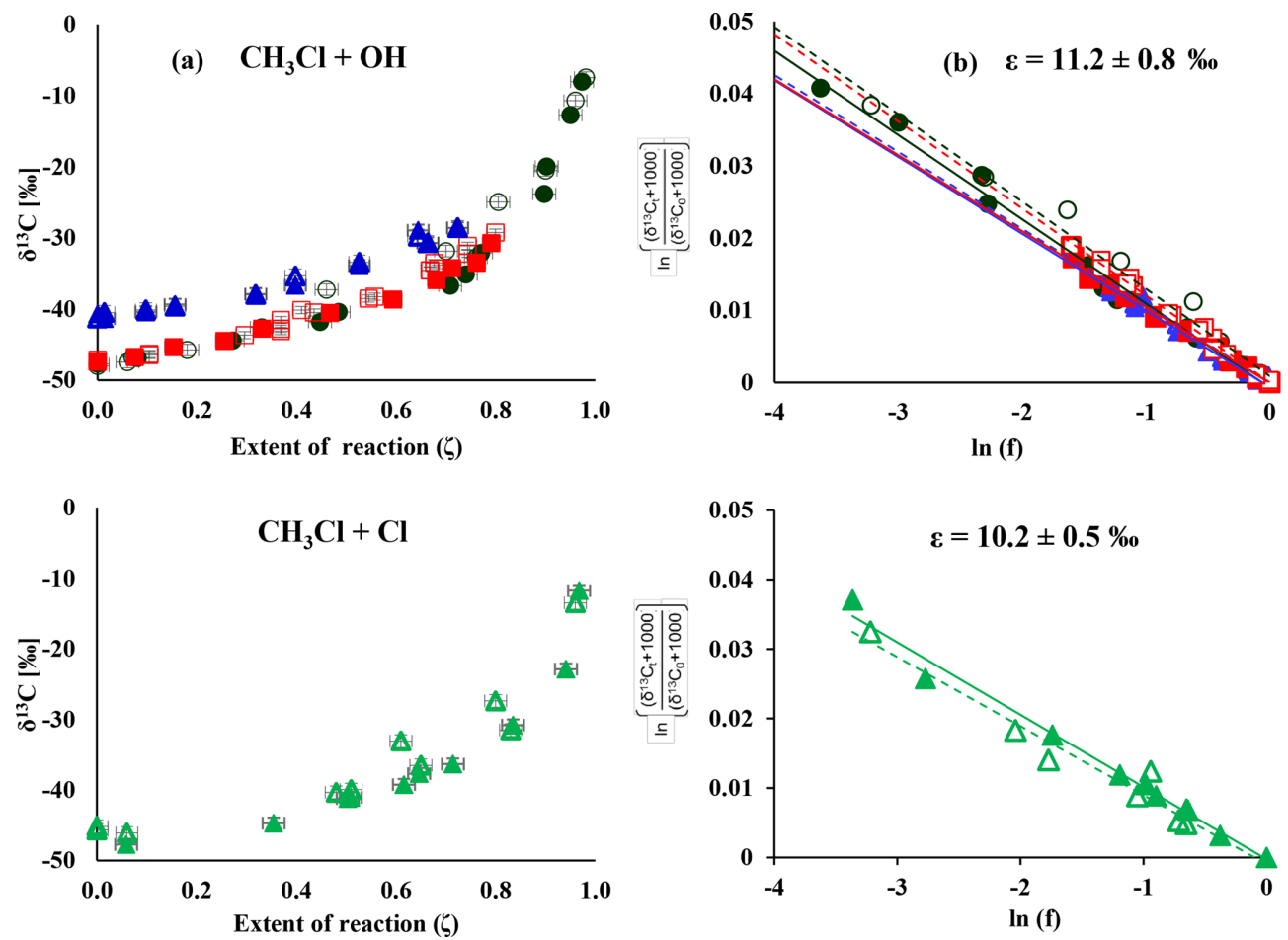

Figure 1. Change in $\delta^{13} \mathrm{C}$ over the extent of the reaction (a) and corresponding Rayleigh plots (b) from the $\mathrm{CH}_{3} \mathrm{Cl}$ degradation experiments. Filled symbols and regression lines refer to the data from Heidelberg; open symbols and dashed regression lines show data from Hamburg. The colours refer to different degradation experiments (black is experiment 1, red is experiment 2, blue is experiment 4 and green is experiment 7). Errors in $\zeta$ were $\pm 2 \%$ on the $1 \sigma$ level. Errors in $\delta^{13} \mathrm{C}$, derived from the regression analysis, ranged from $\pm 0.4 \%$ o to $\pm 1.4 \%$ on the $1 \sigma$ level.

Table 2. Summary of the kinetic isotope effects $(\varepsilon)$ for the reaction of $\mathrm{CH}_{3} \mathrm{Cl}$ and $\mathrm{CH}_{4}$ with $\mathrm{OH}$ and $\mathrm{Cl}$ from this study. We used an orthogonal regression to calculate $\varepsilon$ and the respective uncertainties on the $1 \sigma$ level for each experiment. In experiment 4 the $\varepsilon$ for methane has not been determined.

\begin{tabular}{llrr|rr}
\hline & & \multicolumn{2}{c|}{ Hamburg } & \multicolumn{2}{c}{ Heidelberg } \\
\cline { 3 - 6 } & & $\varepsilon$ & $R^{2}$ & $\varepsilon$ & $R^{2}$ \\
\hline Experiment 1 & $\mathrm{CH}_{3} \mathrm{Cl}+\mathrm{OH}$ & $-12.1 \pm 0.6$ & 0.95 & $-11.7 \pm 0.4$ & 0.99 \\
Experiment 2 & & $-12.1 \pm 0.3$ & 0.99 & $-10.5 \pm 0.3$ & 0.99 \\
Experiment 4 & & $-10.4 \pm 0.4$ & 0.99 & $-10.6 \pm 0.6$ & 0.99 \\
Experiment 7 & $\mathrm{CH}_{3} \mathrm{Cl}+\mathrm{Cl}$ & $-10.3 \pm 0.7$ & 0.96 & $-10.4 \pm 0.4$ & 0.98 \\
Experiment 5 & $\mathrm{CH}_{4}+\mathrm{OH}$ & & & $-4.7 \pm 0.2$ & 0.99 \\
Experiment 8 & $\mathrm{CH}_{4}+\mathrm{Cl}$ & & & $-59.0 \pm 1.3$ & 0.99 \\
\hline
\end{tabular}

contribution of $9 \%$ from the reaction with $\mathrm{O}\left({ }^{1} \mathrm{D}\right)$ is required to explain the difference in terms of $\mathrm{O}\left({ }^{1} \mathrm{D}\right)$ loss.

\subsection{Discussion of the $\mathrm{CH}_{3} \mathrm{Cl}$ degradation experiments}

Our newly determined isotope effects for the reaction of $\mathrm{CH}_{3} \mathrm{Cl}$ with $\mathrm{OH}$ and $\mathrm{Cl}$ are 5 to 6 times smaller than the previously reported $\varepsilon$ values of $(-59 \pm 10) \%$ for the reaction with $\mathrm{OH}$ and of $(-70 \pm 10) \%$ of for the reaction with $\mathrm{Cl}$ (Gola et al., 2005). In this section, we first discuss potential sources of error in our study with particular respect to the differences between our study and the Gola study and then provide a more comprehensive comparison of our data with previous data. Gola et al. (2005) used a $250 \mathrm{dm}^{3}$ electro polished stainless steel chamber for their degradation experiments. We used a $3500 \mathrm{dm}^{3}$ smog chamber, made of FEP foil, for the $\mathrm{CH}_{3} \mathrm{Cl}$ degradation experiments. The large volume of our smog chamber may result in incomplete mixing and thus in an underestimation of the KIE due to transport limitation. The effect of mixing on the observed KIE can be approximated from the timescales of mixing and reaction according to the following equation (Morgan et al., 2004; Kaiser et al., 
Table 3. Compilation of kinetic isotope effects $(\varepsilon)$ for the reaction of $\mathrm{CH}_{3} \mathrm{Cl}, \mathrm{CH}_{4}$ and alkanes with $\mathrm{OH}$ and $\mathrm{Cl}$.

\begin{tabular}{|c|c|c|c|}
\hline Reaction & $\varepsilon$ & Method & Reference \\
\hline $\mathrm{CH}_{3} \mathrm{Cl}+\mathrm{OH}$ & $\begin{array}{r}-58 \pm 10 \\
-44 \\
-3.6 \\
-5 \pm 3 \\
-11.2 \pm 0.8\end{array}$ & $\begin{array}{l}\text { smog chamber; } \mathrm{O}_{3}+\mathrm{H}_{2}+h v(254 \mathrm{~nm}), \text { FTIR } \\
\text { theoretical at } 298 \mathrm{~K} \\
\text { theoretical } \\
\text { derived from field data } \\
\text { smog chamber; } \mathrm{O}_{3}+\mathrm{H}_{2} \mathrm{O}+h v(254 \mathrm{~nm}), \mathrm{GC}-\mathrm{IRMS}\end{array}$ & $\begin{array}{l}\text { Gola et al. (2005) } \\
\text { Feilberg et al. (2005) } \\
\text { Jalili and Akhavan (2006) } \\
\text { Thompson et al. (2002) } \\
\text { This study }\end{array}$ \\
\hline $\mathrm{CH}_{3} \mathrm{Cl}+\mathrm{Cl}$ & $\begin{array}{r}-70 \pm 10 \\
-35 \\
-10.4 \pm 0.5\end{array}$ & $\begin{array}{l}\text { smog chamber; } \mathrm{Cl}_{2}+h v(370 \mathrm{~nm}), \mathrm{FTIR} \\
\text { theoretical at } 298 \mathrm{~K} \\
\text { smog chamber; } \mathrm{Cl}_{2}+h v, \mathrm{GC}-\mathrm{IRMS}\end{array}$ & $\begin{array}{l}\text { Gola et al. (2005) } \\
\text { Feilberg et al. (2005) } \\
\text { This study }\end{array}$ \\
\hline $\mathrm{CH}_{4}+\mathrm{OH}$ & $\begin{array}{l}-3.9 \pm 0.4 \\
-5.4 \pm 0.9 \\
-4.7 \pm 0.2\end{array}$ & $\begin{array}{l}\text { photoreactor; } \mathrm{H}_{2} \mathrm{O}_{2}+h v, \mathrm{GC}-\mathrm{IRMS} \\
\text { photoreactor, } \mathrm{O}_{3}+\mathrm{H}_{2} \mathrm{O}+h v(254 \mathrm{~nm}), \mathrm{GC}-\mathrm{IRMS} \\
\text { smog chamber; } \mathrm{O}_{3}+\mathrm{H}_{2} \mathrm{O}+\mathrm{hv}(254 \mathrm{~nm}), \mathrm{GC}-\mathrm{IRMS}\end{array}$ & $\begin{array}{l}\text { Saueressig et al. (2001) } \\
\text { Cantrell et al. (1990) } \\
\text { This study }\end{array}$ \\
\hline $\mathrm{CH}_{4}+\mathrm{Cl}$ & $\begin{array}{r}-58 \pm 2 \\
-66 \pm 2 \\
-62 \pm 0.1 \\
-59 \pm 1.3\end{array}$ & $\begin{array}{l}\text { smog chamber; } \mathrm{Cl}_{2}+h v \text { FTIR } \\
\text { photoreactor; } \mathrm{Cl}_{2}+h v ; \text { TDLAS } \\
\text { smog chamber; } \mathrm{Cl}_{2}+h v ; \text { DI-IRMS } \\
\text { smog chamber; } \mathrm{Cl}_{2}+h v \text { GC-IRMS }\end{array}$ & $\begin{array}{l}\text { Sellevåg et al. (2006) } \\
\text { Saueressig et al. (1995) } \\
\text { Tyler et al. (2000) } \\
\text { This study }\end{array}$ \\
\hline $\mathrm{C}_{2} \mathrm{H}_{6}+\mathrm{OH}$ & $-7.5 \pm 0.5$ & reaction chamber; $\mathrm{H}_{2} \mathrm{O}_{2}+h v ; \mathrm{GC}-\mathrm{IRMS}$ & Piansawan et al. (2017) \\
\hline $\mathrm{R}-\mathrm{CH}_{3}+\mathrm{OH}$ & $-18.7 \pm 5.2$ & reaction chamber; $\mathrm{R}-\mathrm{NO}_{2}, \mathrm{NO}+h v ; \mathrm{GC}-\mathrm{IRMS}$ & Anderson et al. (2004) \\
\hline $\mathrm{R}-\mathrm{CH}_{3}+\mathrm{Cl}$ & $-18.6 \pm 0.3$ & reaction chamber; $\mathrm{Cl}_{2}+h v ; \mathrm{GC}-\mathrm{IRMS}$ & Anderson et al. (2007) \\
\hline
\end{tabular}

2006):

$\epsilon_{\mathrm{obs}} \approx \frac{1}{2} \varepsilon_{\mathrm{i}} \times\left(1+\sqrt{\frac{1}{1+Q}}\right)$.

Here, $\varepsilon_{\mathrm{i}}$ is the intrinsic fractionation factor, $\epsilon_{\mathrm{obs}}$ is the observed fractionation factor and $Q$ is the ratio of the mixing time and reaction timescale $(1 / k)$. The chemical lifetime of $\mathrm{CH}_{3} \mathrm{Cl}$ under the experimental conditions was in the order of 6 to $8 \mathrm{~h}$ and the turnover of air inside the chamber occurred on timescales of a few minutes. With a reaction timescale of 300 minutes and a mixing timescale of $10 \mathrm{~min}$ we obtain $\varepsilon_{\text {obs }} \approx 0.99 \times \varepsilon_{\mathrm{i}}$, making incomplete mixing an unlikely source of error. Incomplete mixing would also have affected the determination of the respective KIEs for $\mathrm{CH}_{4}$. With those values being within previously reported $\varepsilon$ values, we can exclude incomplete mixing as a potential source of error in our experiments. In the Gola et al. (2005) study, the mixing ratios and isotope ratios were determined with longpath FTIR. In our study, the mixing ratios were determined by GC-MS and the isotope ratios were measured by GCIRMS in two different laboratories. Both labs used different analytical set-ups, different sampling methods and different standards. However, the results from both labs generally agree within $\pm 1.5 \%$ on the $1 \sigma$ level and show no systematic difference. As outlined before, different initial $\delta^{13} \mathrm{C}\left(\mathrm{CH}_{3} \mathrm{Cl}\right)$ as well as different initial $\mathrm{CH}_{3} \mathrm{Cl}$ mixing ratios had no significant effect on the determination of the isotope effects. This makes analytical artefacts in our $\delta^{13} \mathrm{C}$ determination unlikely. The $\mathrm{Cl}$ radical generation scheme was quite simi- lar among both studies. Gola et al. (2005) used narrowband photolysis of $\mathrm{Cl}_{2}$, employing a Philips TLD-08 fluorescent lamp ( $\lambda \max \sim 370) \mathrm{nm}$, whereas we used broadband photolysis (300 to $700 \mathrm{~nm}$ ), making this an unlikely source for the discrepancy in between the isotope effects for the reaction of $\mathrm{CH}_{3} \mathrm{Cl}$ with $\mathrm{Cl}$.

In our study, $\mathrm{OH}$ was generated via UV photolysis of ozone (steady-state mixing ratios of 0.62 and $3.6 \mu \mathrm{mol} \mathrm{mol}^{-1}$ ) in the presence of water vapour (RH of $70 \%$ ) and $2000 \mu \mathrm{mol} \mathrm{mol}^{-1} \mathrm{H}_{2}$, whereas in the Gola study $\mathrm{OH}$ was generated in the absence of water vapour from the reaction of $\mathrm{O}\left({ }^{1} \mathrm{D}\right)$ with $\mathrm{H}_{2}\left(2000 \mu \mathrm{mol} \mathrm{mol}^{-1}\right)$ after $\mathrm{UV}$ photolysis of ozone $\left(300 \mu \mathrm{mol} \mathrm{mol}^{-1}\right)$. Due to the much lower ozone mixing ratios employed in our study, the $\mathrm{OH}$ generation in the absence of water vapour was not sufficient in our study. Both $\mathrm{OH}$ generation schemes are well established. However, Cantrell et al. (1990), who used UVphotolysis in the presence of water as an $\mathrm{OH}$ source, estimated that the reaction of $\mathrm{CH}_{4}$ with $\mathrm{O}\left({ }^{1} \mathrm{D}\right)$ may contribute about $3 \%$ to the overall degradation. The higher ozone levels and the less efficient conversion of $\mathrm{O}\left({ }^{1} \mathrm{D}\right)$ to $\mathrm{OH}$ in the Gola et al. (2005) study suggest an overall higher transient $\mathrm{O}\left({ }^{1} \mathrm{D}\right)$ concentration compared to our experiments. Anyhow, interference from the reaction with $\mathrm{O}\left({ }^{1} \mathrm{D}\right)$ is less likely for $\mathrm{CH}_{3} \mathrm{Cl}$ than for $\mathrm{CH}_{4}$. The reaction rate for $\mathrm{CH}_{4}$ with $\mathrm{O}\left({ }^{1} \mathrm{D}\right)\left(1.7 \times 10^{-10} \mathrm{~cm}^{3} \mathrm{~s}^{-1}\right.$; Burkholder et al., 2015) is $2.7 \times 10^{4}$ times larger than the respective reaction rate for $\mathrm{OH}\left(6.3 \times 10^{-15} \mathrm{~cm}^{3} \mathrm{~s}^{-1}\right)$. In the case of $\mathrm{CH}_{3} \mathrm{Cl}$, the ratio is only $7.4 \times 10^{3}\left(2.6 \times 10^{-10}\right.$ and $3.5 \times 10^{-14} \mathrm{~cm}^{3} \mathrm{~s}^{-1}$; 
Burkholder et al., 2015). Assuming a contribution of $9 \%$ from the reaction with $\mathrm{O}^{1} \mathrm{D}$ in the $\mathrm{CH}_{4}$ experiment, the reaction with $\mathrm{O}\left({ }^{1} \mathrm{D}\right)$ should contribute less than $2.3 \%$ to the observed $\mathrm{CH}_{3} \mathrm{Cl}$ loss. In the $\mathrm{CH}_{3} \mathrm{Cl}$ control experiment, all experimental parameters besides the relative humidity and hence the $\mathrm{OH}$ yields were comparable to $\mathrm{CH}_{3} \mathrm{Cl}$ degradation experiments with $\mathrm{OH}$. The $\mathrm{CH}_{3} \mathrm{Cl}$ loss of less than $3 \%$ over $10 \mathrm{~h}$ can most likely be attributed to a reaction with $\mathrm{OH}$, originating from the reaction of $\mathrm{O}\left({ }^{1} \mathrm{D}\right)$ with $\mathrm{H}_{2}$. The $\delta^{13} \mathrm{C}$ values of $\mathrm{CH}_{3} \mathrm{Cl}$ were $-46.8 \%$ at the beginning and $-46.1 \%$ after $10 \mathrm{~h}$, which are indistinguishable within the measurement uncertainty. This experiment makes any biasing side reactions unlikely. In any case we can limit the loss from potential side reactions to less than $3 \%$. In addition, none of our tests prior each degradation experiment revealed an indication of a measurable loss of $\mathrm{CH}_{3} \mathrm{Cl}$. With this, we can safely exclude any measurable effect from potential side reactions on the determination of the KIEs in our study.

A comparison of our data with previously measured and calculated isotope effects for the reaction of $\mathrm{CH}_{3} \mathrm{Cl}, \mathrm{CH}_{4}$ and other VOCs with $\mathrm{OH}$ and $\mathrm{Cl}$ is provided in Table 3. In a follow-up study to Gola et al. (2005), Sellevåg et al. (2006) attributed these exceptionally large fractionation factors to higher internal barriers of rotation of the $\mathrm{OH}$ radical compared to the $\mathrm{CH}_{4}+\mathrm{OH}$ reaction. Using variational transition state theory, the authors calculated $\varepsilon$ values of $-47 \%$ and $-37 \%$ for the reaction of $\mathrm{CH}_{3} \mathrm{Cl}$ with $\mathrm{OH}$ and $\mathrm{Cl}$, respectively. However, a simultaneous theoretical study provided an $\varepsilon$ value of only $-3.6 \%$ for the reaction of $\mathrm{CH}_{3} \mathrm{Cl}$ with $\mathrm{OH}$ (Jalili and Akhavan, 2006). For C-H bond breakage, Streitwieser's semi-classical limit for isotope effects is $-21 \%$ o (Elsner et al., 2005), and for reactions involving hydrogen radical transfer, an $\varepsilon$ value of $-15 \%$ has been reported (Merrigan et al., 1990). Both values support a lower fractionation factor. For the reaction of ethane with $\mathrm{OH}$, which can be approximately regarded as a substituted methane, an $\varepsilon$ value of $(-7.5 \pm 0.5) \%$ has been reported (Piansawan et al., 2017). One can estimate an upper limit for the reactive site by multiplying $\delta^{13} \mathrm{C}$ with the number of carbon atoms in the molecule (Anderson et al., 2004). This leads to an upper limit of $(-15.0 \pm 0.7) \%$ o for the $\varepsilon$ value at the reactive centre. In line with this, Anderson et al. (2004) reported a group kinetic isotope effect of $(-18.7 \pm 5.2) \%$ o for the reaction of primary carbon atoms of alkanes with $\mathrm{OH}$. The same group (Anderson et al., 2007) found a group kinetic isotope effect of $(-18.6 \pm 0.3) \%$ o for the respective reaction with $\mathrm{Cl}$. Our smaller kinetic isotope effect for the reaction of $\mathrm{CH}_{3} \mathrm{Cl}$ with $\mathrm{OH}$ and $\mathrm{Cl}$ is much closer to these group-specific kinetic isotope effects than the previously reported ones from Gola et al. (2005).

To this end, the large discrepancy between our data and those of Gola et al. (2005) remains unresolved and cannot be explained from experimental details. However it appears that the authors have not tested the accuracy of their isotope ratio measurements as a function of the isotopologue mole frac- tion in the presence of other species with overlapping spectra $\left(\mathrm{HCl}, \mathrm{H}_{2} \mathrm{O}, \mathrm{O}_{3}\right.$, etc.), e.g. by using a dilution series.

In any case, the strongest support for our smaller isotope effects arises from the absence of any significant seasonal variation in the tropospheric $\delta^{13} \mathrm{C}\left(\mathrm{CH}_{3} \mathrm{Cl}\right)$, as shown in Sect. 3.5.

\section{Carbon isotope modelling}

\subsection{Model set-up}

The model used in this study is similar to previous two box models (Tans, 1997; Sapart et al., 2012; Saltzman et al., 2004; Trudinger et al., 2004). The atmosphere is divided in two well-mixed semi-hemispheric boxes, representing the Northern and the Southern Hemisphere, and the interhemispheric exchange time is 360 days. The model simulates the major sources and sinks for both the lighter $\left({ }^{12} \mathrm{CH}_{3} \mathrm{Cl}\right)$ and the heavier isotopologue $\left({ }^{13} \mathrm{CH}_{3} \mathrm{Cl}\right)$, as described by Sapart et al. (2012) for $\mathrm{CH}_{4}$. The source and sink terms from the Xiao et al. (2010) model study serve as a starting point for our model. We use a simplified mass balance with four source categories that has distinct isotopic source signatures: higher plants/unknown, oceans, biomass burning and other known sources (Sect. 3.3 and Table 4). Total net emissions were fixed at $4010 \mathrm{Gg} \mathrm{a}^{-1}$ with $2210 \mathrm{Gg} \mathrm{a}^{-1}$ in the Northern Hemisphere and $1800 \mathrm{Gg} \mathrm{a}^{-1}$ in the Southern Hemisphere. For each source category, the carbon isotope source signature was randomly varied within the given uncertainties (Table 4). Losses are specified by pseudo first-order rate coefficients. The sinks implemented in the model (Sect. 3.4 and Table 4) are losses due to the reaction with $\mathrm{OH}$, losses to the surface ocean, losses to soils and losses to the stratosphere. Seasonal variations were modelled with a time step of 1 day, using monthly averaged source terms. Variations in the source composition were modelled with a time step of 90 days, using annually averaged source terms.

\subsection{Mixing ratios and isotopic composition of tropospheric $\mathrm{CH}_{3} \mathrm{Cl}$}

Tropospheric $\mathrm{CH}_{3} \mathrm{Cl}$ has a mean global mixing ratio of about $540 \mathrm{pmol} \mathrm{mol}^{-1}$ (Monzka et al., 2010; Carpenter et al., 2014) and shows a pronounced seasonal cycle with an amplitude of $85 \mathrm{pmol} \mathrm{mol}^{-1}$ at Northern Hemispheric midlatitudes, (Prinn et al., 2000; Yoshida et al., 2006), reflecting the seasonality in the $\mathrm{OH}$ sink (Fig. 2, upper panel).

Reported mean $\delta^{13} \mathrm{C}$ values of tropospheric $\mathrm{CH}_{3} \mathrm{Cl}$ range from $(-36.2 \pm 1.9) \%$ o to $(-40.8 \pm 3.0) \%$ o (Tsunogai et al., 1999; Thompson et al., 2002; Redeker et al., 2007; Bahlmann et al., 2011; Weinberg et al., 2014), suggesting an overall mean $\delta^{13} \mathrm{C}\left(\mathrm{CH}_{3} \mathrm{Cl}\right)$ of $(-37.1 \pm 2.7) \%$ o. In a year-round study carried out in Alert, Canada, Thompson et al. (2002) found no seasonal trend in the tropospheric $\left.\delta^{13} \mathrm{C}_{(\mathrm{CH}} \mathrm{Cl}\right)$ and no clear correlation between the $\mathrm{CH}_{3} \mathrm{Cl}$ mixing and iso- 
Table 4. Simplified $\mathrm{CH}_{3} \mathrm{Cl}$ source and sink scheme used in the model.

\begin{tabular}{lrr|rr}
\hline & \multicolumn{2}{c}{ Strength $\left(\mathrm{Gg} \mathrm{a}^{-1}\right)$} & $\delta^{13} \mathrm{C}$ (source) $/ \varepsilon$ (sink) (\%o) \\
\cline { 2 - 5 } Sources & Best & Range & Best & Range (1 $\sigma)$ \\
\hline Biomass burning & 910 & $655-1125$ & -47 & -40 to -52 \\
Oceans & 335 & $210-480$ & -36 & -30 to -42 \\
Higher plants/unknown & 2400 & $0-3095$ & -83 & -70 to -96 \\
Other known sources & 365 & $79-1016$ & -45 & -39 to -51 \\
\hline sinks & & & & \\
\hline OH, Cl & 3614 & $3564-3000$ & $-11.2 /-59$ & \\
Soils* & 250 & $200-1000$ & -37 & -46 to -2 \\
Stratosphere & 146 & 0 & & \\
\hline
\end{tabular}

* The apparent isotope effect of the soil sink depends on its strength. See text for more details.
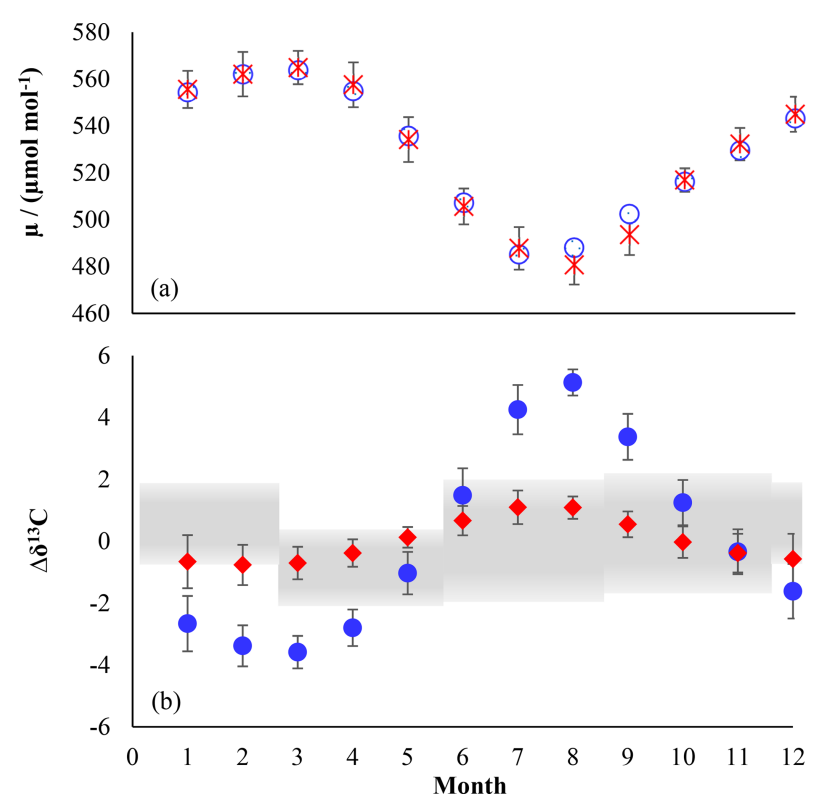

Figure 2. (a) Comparison of modelled northern hemispheric mixing ratios (blue open diamonds) with measured mixing ratios at Mace Head, Ireland (red crosses) for the period from 2004 to 2014 (Prinn et al., 2000). Error bars indicate the variations in the monthly means on the $1 \sigma$ level. (b) Modelled seasonal fluctuations in the $\delta^{13} \mathrm{C}$ of northern hemispheric $\mathrm{CH}_{3} \mathrm{Cl}$ using an $\varepsilon$ of $-11.2 \%$ (red filled diamonds) and an $\varepsilon$ of $-59 \%$ (blue filled dots) as reported by Gola et al. (2005). The panel shows monthly averages from a 10-year simulation with seasonal variations of up to $\pm 10 \%$ in the combined isotopic source signature. Error bars indicate the variations in the monthly means on the $1 \sigma$ level. The grey shaded area shows reported seasonal variations (seasonal mean $\pm 1 \sigma$ ) from Thompson et al. (2002).

tope ratios (Fig. 2, lower panel). From their data the authors estimated the $\varepsilon$ value for the $\mathrm{OH}$ sink at less than $-5 \%$. Including samples from Frazer Point (Canada), Vancouver (Canada), Houston (Texas, USA) and Barring Head (New
Zealand), this study further revealed no indication of a latitudinal trend in tropospheric $\delta^{13} \mathrm{C}\left(\mathrm{CH}_{3} \mathrm{Cl}\right)$. The lack of a significant covariation between the mixing ratios and carbon isotope ratios was confirmed in a second year-round study (Redeker et al., 2007).

\subsection{Sources}

The seasonal source terms are specified for each hemisphere using monthly means as depicted in Fig. 3. The ocean is treated as a net source for $\mathrm{CH}_{3} \mathrm{Cl}$ with an annual net emission of $335 \mathrm{Gg} \mathrm{a}^{-1}$ (range: 80 to $610 \mathrm{Gg} \mathrm{a}^{-1}$ ) (Hu et al., 2013). To account for the bidirectional nature of the gas exchange across the air-sea interface, net fluxes are broken down into unidirectional gross uptake and emission fluxes, with the uptake carrying the isotopic composition of the atmosphere and the emission carrying the isotopic information of the concurrent formation and degradation processes in the ocean. The gross uptake is calculated using an average transfer velocity of $17 \mathrm{~cm} \mathrm{~h}^{-1}$ for $\mathrm{CO}_{2}$ (Wanninkhof, 2014) and a mean tropospheric mixing ratio of $540 \mathrm{pmol} \mathrm{mol}^{-1}$. Gross emissions are then calculated as the difference between net emissions and gross uptake fluxes. The reader should note that this approach differs from that of $\mathrm{Hu}$ et al. (2013) and results in larger gross fluxes because gross fluxes are calculated for the entire ocean surface. Keppler et al. (2005) estimated average isotopic composition of dissolved $\mathrm{CH}_{3} \mathrm{Cl}$ to $(-36 \pm 4) \%$ o. This value refers to Komatsu et al. (2004), who reported a mean $\delta^{13} \mathrm{C}$ of $-38 \%$ for $\mathrm{CH}_{3} \mathrm{Cl}$ in coastally influenced waters off Japan and more enriched $\delta^{13} \mathrm{C}$ values in the range of $-12 \%$ o to $-30 \%$ o from the open north-eastern Pacific. We obtained average $\delta^{13} \mathrm{C}$ values of $-43 \pm 3 \%$ from a productive lagoon in southern Portugal (Weinberg et al., 2015). Taking the biotic and abiotic degradation of $\mathrm{CH}_{3} \mathrm{Cl}$ into account, we estimate the mean isotopic source signature of the ocean source to be $(-36 \pm 6) \%$.

We applied a source strength of $910 \mathrm{Gg} \mathrm{a}^{-1}$ for biomass burning (range from 660 to $1230 \mathrm{Gg} \mathrm{a}^{-1}$ ) with $68 \%$, orig- 

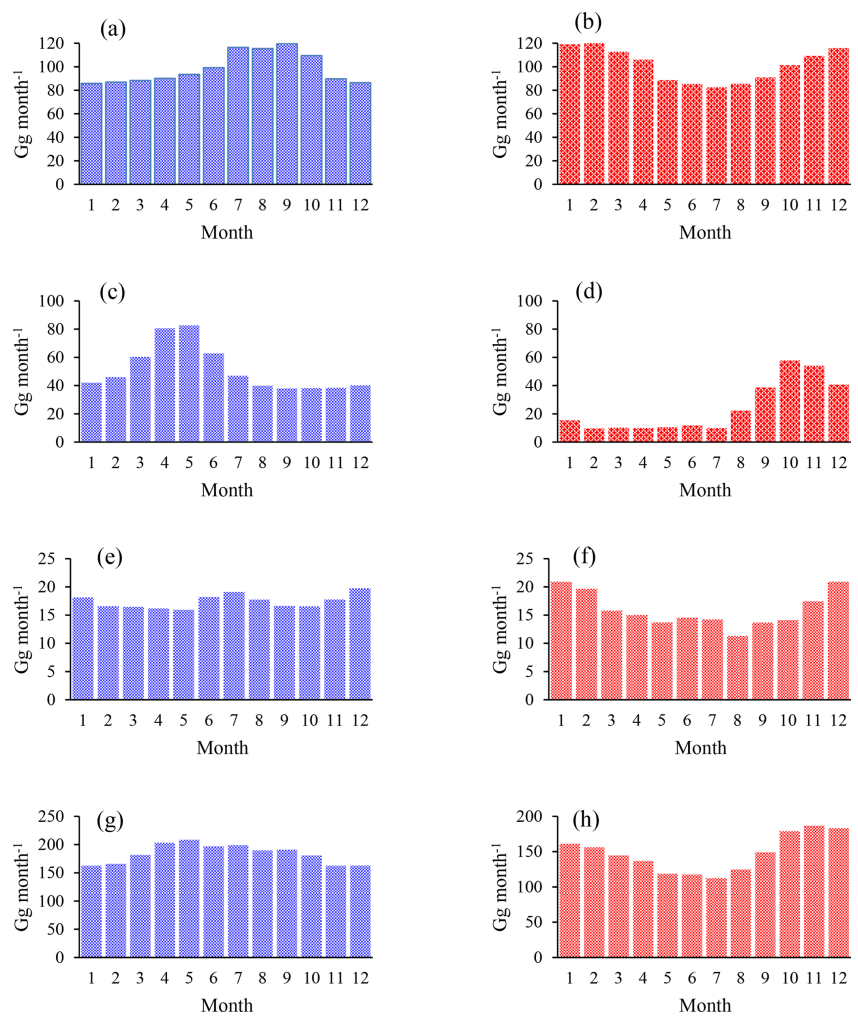

Figure 3. Chloromethane emissions in $\mathrm{Gg}_{\text {month }}{ }^{-1}$ for the Northern $(\mathbf{a}, \mathbf{c}, \mathbf{e}, \mathbf{g})$ and Southern Hemisphere $(\mathbf{b}, \mathbf{d}, \mathbf{f}, \mathbf{h})$. (a, b) Combined emissions from higher plants and the unknown source, (c, d) biomass burning, (e, f) ocean net emission fluxes, and $(\mathbf{g}, \mathbf{h})$ total emissions. The emissions from the other known sources are constant over time, with $22.8 \mathrm{Gg}_{\text {month }}{ }^{-1}$ in the Northern Hemisphere and $7.6 \mathrm{Gg}$ month $^{-1}$ in the Southern Hemisphere.

inating from the Northern Hemisphere, and the emissions peaking during hemispheric spring (Xiao et al., 2010). $\mathrm{CH}_{3} \mathrm{Cl}$ from biomass burning shows a $\delta^{13} \mathrm{C}$ of $(-47 \pm 7) \%$ o (Czapiewski et al., 2002; Thompson et al., 2002).

The category "other known sources" comprises fungi wetlands and anthropogenic emissions with a total source strength of $365 \mathrm{Gg} \mathrm{a}^{-1}$ (range: 79 to $1016 \mathrm{Gg} \mathrm{a}^{-1}$ ) and an averaged isotopic source signature of $(-45.5 \pm 5.5) \%$ calculated from the source signatures given by Keppler et al. (2005). The emissions from the other known sources were constant over time with $274 \mathrm{Gg} \mathrm{a}^{-1}$ in the Northern Hemisphere and $91 \mathrm{Gg} \mathrm{a}^{-1}$ in the Southern Hemisphere.

The source category "higher plants/missing" (900 to $3095 \mathrm{Gg} \mathrm{a}^{-1}$ ) mainly represents emissions from the tropical rainforest ( 900 to $2650 \mathrm{Gg} \mathrm{a}^{-1}$ ) with minor contributions from salt marshes ( 80 to $160 \mathrm{Gg} \mathrm{a}^{-1}$ ), rice paddies $\left(5 \mathrm{Gg} \mathrm{a}^{-1}\right)$ and mangroves $\left(\sim 50 \mathrm{Gg} \mathrm{a}^{-1}\right)$. These emissions are almost equally distributed between the hemispheres and show a slight seasonal peak during hemispheric summer. In order to evaluate the emissions from higher plants, these emissions were divided into two fractions by introducing a split fac- tor. The first fraction represents "true" emissions from higher plants, having an exceptionally depleted isotopic source signature of $(-83 \pm 15) \%$ (Saito and Yokouchi, 2008; Saito et al., 2008). The second fraction represents an unknown or missing source. The $\delta^{13} \mathrm{C}$ of this source is scaled to match the $\delta^{13} \mathrm{C}$ of tropospheric $\mathrm{CH}_{3} \mathrm{Cl}$. A more depleted $\delta^{13} \mathrm{C}$ for this source would point towards additional contributions from a lighter source, such as senescent leaf litter, whereas a more enriched $\delta^{13} \mathrm{C}$ for this source points towards additional contributions from a more enriched source.

Saito et al. (2013) recently reported on the bidirectional exchange of $\mathrm{CH}_{3} \mathrm{Cl}$ across the leaves of tropical plants with gross uptake rates being roughly a sixth of gross emission rates. The authors hypothesized that the gross uptake may be related to endosymbiotic bacteria. This uptake might affect the isotopic composition of $\mathrm{CH}_{3} \mathrm{Cl}$ from tropical rainforests. However, because the incubation methods used in this study were the same as those previously used to determine the isotopic composition of $\mathrm{CH}_{3} \mathrm{Cl}$ emitted from tropical plants (Saito and Yokouchi, 2008; Saito et al., 2008), we can reasonably assume that any potential isotopic effect of this bidirectional exchange is included in the previously reported carbon isotope ratios.

\subsection{Sinks}

The reaction with $\mathrm{OH}$ constitutes the single largest sink for $\mathrm{CH}_{3} \mathrm{Cl}$, accounting for approximately $80 \%$ of its removal from the troposphere. For this study, we used the $\mathrm{OH}-$ concentration fields from Spivakovsky et al. (2000) along with reaction rate constants of Burkholder et al. (2015) to derive monthly resolved lifetimes for both hemispheres. The monthly loss rates were then forced to reproduce seasonal variations of the mixing ratios at Mace Head in the Northern Hemisphere and at Cape Grim, Tasmania, in the Southern Hemisphere (Prinn et al., 2000). This resulted in a total tropospheric sink $(\mathrm{OH}+\mathrm{Cl})$ of $3614 \mathrm{Gg} \mathrm{a}^{-1}$, which is comparable to previous modelling studies (Xiao et al., 2010).

In most global budgets, soils are treated as a small sink for chloromethane of about $\sim 250 \mathrm{Gg} \mathrm{a}^{-1}$, though a larger uptake exceeding $1000 \mathrm{Gg} \mathrm{a}^{-1}$ has been suggested (Keppler et al., 2005; Carpenter et al., 2014). Based on Xiao et al. (2010), we a priori assumed a soil sink of $250 \mathrm{Gg} \mathrm{a}^{-1}$ with northern and southern hemispheric fractions of 180 and $70 \mathrm{Gg} \mathrm{a}^{-1}$, reflecting the interhemispheric distribution of the land masses.

The microbial degradation of $\mathrm{CH}_{3} \mathrm{Cl}$ in soils is assigned with a large carbon isotope effect of $-47 \%$ o (Miller et al., 2001, 2004). The only study we are aware of (Redeker and Kalin, 2012) that investigates the isotopic composition of soil derived $\mathrm{CH}_{3} \mathrm{Cl}$ reports a $\delta^{13} \mathrm{C}$ of $(-34 \pm 14) \%$. The soil uptake of $\mathrm{CH}_{3} \mathrm{Cl}$ can be regarded as a coupled diffusion reaction process, where $\mathrm{CH}_{3} \mathrm{Cl}$ is first transported into the soil and then undergoes microbial degradation. The apparent isotope effect of such coupled processes will depend on the isotope effects of both steps and can be estimated from diffusion 
reaction models (Farquhar et al., 1982):

$\varepsilon_{\mathrm{app}}=\varepsilon_{\mathrm{d}}+\frac{\left(\epsilon_{\mathrm{m}}-\varepsilon_{\mathrm{d}}\right) \times\left(m_{\mathrm{d}}-m_{\mathrm{m}}\right)}{m_{\mathrm{d}}}$,

with $\varepsilon_{\mathrm{d}}$ and $\varepsilon_{\mathrm{m}}$ being the kinetic isotope effects assigned to microbial degradation (47\%o) and diffusion (4\%o), and where $m_{\mathrm{d}}$ is the total mass of $\mathrm{CH}_{3} \mathrm{Cl}$ that enters the soil via diffusion and $m_{\mathrm{m}}$ represents the net soil sink.

The gross uptake flux $\left(m_{\mathrm{d}}\right)$ was estimated using a simple transfer resistance model along with the biomes and respective active seasons as previously employed by Shorter et al. (1995). We used an overall atmospheric transfer resistance governing the transport to the soil surface (aerodynamic transport resistance, quasi-laminar sublayer resistance and in canopy transfer resistance) of $4 \mathrm{~s} \mathrm{~cm}^{-1}$, regardless of the biome, that was derived from reported typical transfer resistances for different biomes (Zhang et al., 2003). The soil uptake is governed by molecular diffusion through the airfilled pore space. The soil-side transfer resistance can be estimated from the effective diffusion in the soil column. For a first rough estimate of the soil transfer resistance, we assume an air-filled pore space of $0.3(V / V)$ and a microbial inactive soil layer of $0.5 \mathrm{~cm}$ at the soil surface. Using the Penman model (Penman, 1940) and a diffusion coefficient of $0.144 \mathrm{~cm}^{2} \mathrm{~s}^{-1}$ in air, we obtain a soil transfer resistance of $17 \mathrm{~s} \mathrm{~cm}^{-1}$. With a globally averaged transfer resistance of $21 \mathrm{~s} \mathrm{~cm}^{-1}$ and a $\mathrm{CH}_{3} \mathrm{Cl}$ background concentration of $540 \mathrm{pmol} \mathrm{mol}^{-1}$ and the land use categories from Shorter et al. (1995), we obtain an upper limit of $1300 \mathrm{Gg} \mathrm{a}^{-1}$ for $m_{\mathrm{d}}$.

As depicted in Fig. 4, the apparent isotope effect of the soil uptake is bracketed by the isotope effects of both steps and decreases when increasing the net soil uptake. The microbial degradation is rate limiting at low net uptake rates, and the apparent isotope effect of the soil uptake is close to that for microbial degradation. For instance, a soil sink of $250 \mathrm{Gg} \mathrm{a}^{-1}$ reveals an apparent $\varepsilon$ value of $-38 \%$. When the entire chloromethane diffusing into soils is microbially degraded, diffusion becomes the rate-limiting step, and the apparent $\varepsilon$ value matches that of diffusion.

In turn the imprint on the tropospheric $\delta^{13} \mathrm{C}$ shows a parabolic distribution with a maximum at $m_{\mathrm{m}}=0.5 m_{\mathrm{d}}$. The isolated effect of the soil sink would result in a maximum enrichment of $3.8 \%$ in the tropospheric $\delta^{13} \mathrm{C}$ that reduces to $2.1 \%$ when accounting for the concurrent reduction in the $\mathrm{OH}$ sink. In this case, increasing the soil sink could even lead to a decrease in the overall sink isotope effect once the apparent isotope effect of the soil sink becomes smaller than the isotope effect of the $\mathrm{OH}$ sink.

\subsection{Seasonal variations in the $\delta^{13} \mathrm{C}$ of tropospheric $\mathrm{CH}_{3} \mathrm{Cl}$}

The $\mathrm{OH}$-driven seasonal cycle in the tropospheric mixing ratios of $\mathrm{CH}_{3} \mathrm{Cl}$ implies an inverse covariation in the $\delta^{13} \mathrm{C}$ of
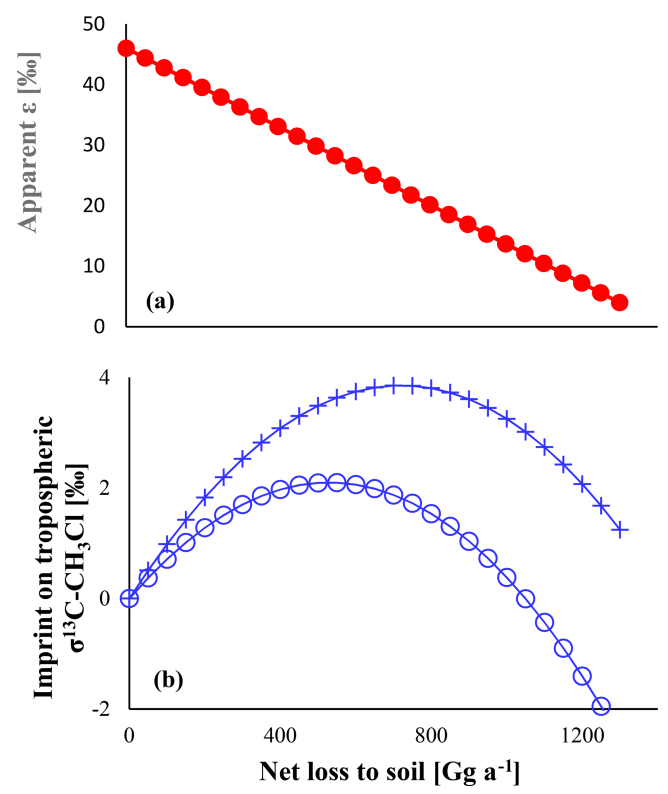

Figure 4. Panel (a) shows the apparent $\varepsilon$ of the soil sink versus the sink strength. Panel (b) shows the resulting effect on tropospheric $\delta^{13} \mathrm{C}$. Crosses show the pure effect, e.g. in the absence of any other fractionating sink. Open circles show the resulting effect with an $\varepsilon$ of $-11.2 \%$ assigned to the $\mathrm{OH}$ sink. Total losses were assumed to be fixed at $4010 \mathrm{Gg} \mathrm{a}^{-1}$.

tropospheric $\mathrm{CH}_{3} \mathrm{Cl}$ to an extent that is closely linked to the kinetic isotope effect of the $\mathrm{OH}$ sink.

Our model resembles mean tropospheric mixing ratios of about $540 \mathrm{pmol} \mathrm{mol}^{-1}$ (Monzka et al., 2010; Carpenter et al., 2014) and the seasonal cycles of $\mathrm{CH}_{3} \mathrm{Cl}$ in both hemispheres within $\pm 4 \%$ (Fig. 2 upper panel). In our simulations, an $\varepsilon$ value of $-59 \%$ for the $\mathrm{OH}$ sink produces an inverse covariation of the $\delta^{13} \mathrm{C}\left(\mathrm{CH}_{3} \mathrm{Cl}\right)$ with the $\mathrm{CH}_{3} \mathrm{Cl}$ mixing ratios with a seasonal amplitude of $9.2 \%$, whereas our new smaller $\varepsilon$ value of $-11.2 \%$ results in a seasonal amplitude of only $1.7 \%$ (Fig. 2 lower panel), fitting quite well to the measured variation given by Thompson et al. (2002).

Random variations of $\pm 10 \%$ in the isotopic source signatures, seasonal variations of the emission functions and variations in the soil sink resulted in seasonal fluctuations of up to $\pm 10 \%$ in the combined isotopic source signature (see Supplement for further details). As already noted by Tans (1997) the large tropospheric background strongly attenuates temporal variations. In our model simulations these seasonal variations in the combined isotopic source signature resulted in systematic seasonal variations of the northern hemispheric $\delta^{13} \mathrm{C}$ of less than $\pm 0.7 \%$ attributable to the isotopic source signal and a scatter of up to $\pm 1.0 \%$ o in the monthly mean $\delta^{13} \mathrm{C}\left(\mathrm{CH}_{3} \mathrm{Cl}\right)$ values in the Northern Hemisphere. In all our model simulations these variations in the combined isotopic source did not significantly affect the differences in the seasonal amplitude of the tropospheric $\delta^{13} \mathrm{C}$ signal. They may have an imprint on the tropospheric 
$\delta^{13} \mathrm{C}\left(\mathrm{CH}_{3} \mathrm{Cl}\right)$ signal when applying an $\varepsilon$ value of $-11.2 \%$ o to the $\mathrm{OH}$ sink. However, they are largely obscured when applying an $\varepsilon$ value of $-59 \%$ o to the OH sink (Fig. S6 in the Supplement). Masking the isotope effect of this large $\varepsilon$ value would require seasonal variations of about $50 \%$ in the combined source signatures that are inversely correlated to the $\mathrm{OH}$ sink. In sum, the lacking covariation between the mixing ratios and carbon isotope ratios strongly supports our new $\varepsilon$ value of $-11.2 \%$ and makes the previously reported larger $\varepsilon$ value highly unlikely.

\subsection{Implications for the tropical rainforest source}

An $\varepsilon$ value of $-59 \%$ for the $\mathrm{OH}$ sink requires a mean massweighted isotopic source composition of $-84.5 \%$ to balance the tropospheric $\delta^{13} \mathrm{C}\left(\mathrm{CH}_{3} \mathrm{Cl}\right)$ of $(-36.4 \pm 2.1) \%$ (Thompson et al., 2002), as shown in previous studies. Apart from large emissions from higher plants (Keppler et al., 2005; Saito and Yokouchi, 2008) in tropical rainforests, this isotope effect suggests additional substantial emissions from an even more depleted source, such as senescent leaf litter (Keppler et al., 2005; Saito and Yokouchi, 2008). In contrast, the revised smaller $\varepsilon$ value of $-11.2 \%$ requires a mean isotopic source signature of $-48.5 \%$, which is close to the mass-weighted $\delta^{13} \mathrm{C}$ of all other known sources excluding higher plants. Along with higher plant emissions of $2200 \mathrm{Gg} \mathrm{a}^{-1}$, the new $\varepsilon$ value of $-11.2 \%$ yields a mean tropospheric $\left.\delta^{13} \mathrm{C}_{(\mathrm{CH}} \mathrm{Cl}\right)$ of $-56 \%$, which is depleted by almost $20 \%$ in comparison to the mean reported tropospheric $\delta^{13} \mathrm{C}\left(\mathrm{CH}_{3} \mathrm{Cl}\right)$.

We performed more than 10000 steady-state runs with random variations in the isotopic composition of tropospheric $\mathrm{CH}_{3} \mathrm{Cl}(-36.4 \pm 2.1 \%$ o), the isotopic source signatures (Table 4) and the isotope effect of the soil sink to assess the range of $\mathrm{CH}_{3} \mathrm{Cl}$ emissions from higher plants. The source category "higher plants" was divided in two fractions, one representing "true" emissions from higher plants and the other representing missing emissions. The $\delta^{13} \mathrm{C}$ of the missing emissions was always scaled to match the tropospheric $\delta^{13} \mathrm{C}\left(\mathrm{CH}_{3} \mathrm{Cl}\right)$.

As shown in Fig. 5, the strength of the tropical rainforest source is directly linked to the strength and isotopic composition of missing emissions. A tropical rainforest source of $(600 \pm 200) \mathrm{Gg} \mathrm{a}^{-1}$ suggests missing emissions of (1600 \pm 200) $\mathrm{Gg} \mathrm{a}^{-1}$, requiring a $\delta^{13} \mathrm{C}$ of $(-45 \pm 6) \%$ to balance the tropospheric $\delta^{13} \mathrm{C}\left(\mathrm{CH}_{3} \mathrm{Cl}\right)$. This $\delta^{13} \mathrm{C}$ is close to the mean isotopic composition of all other known sources. Increasing the emissions from all other known sources within the given ranges might reduce the missing emissions by about $500 \mathrm{Gg} \mathrm{a}^{-1}$. A further increase of the tropical rainforest emissions results in an equivalent reduction in missing emissions but requires a more enriched $\delta^{13} \mathrm{C}$ for the missing emissions. For instance, balancing a tropical rainforest source of $(1100 \pm 200) \mathrm{Gg} \mathrm{a}^{-1}$ requires missing emissions of the same magnitude with a $\delta^{13} \mathrm{C}$ of $(-31 \pm 6) \%$. This is at the upper end of reported source signatures and may thus serve as a

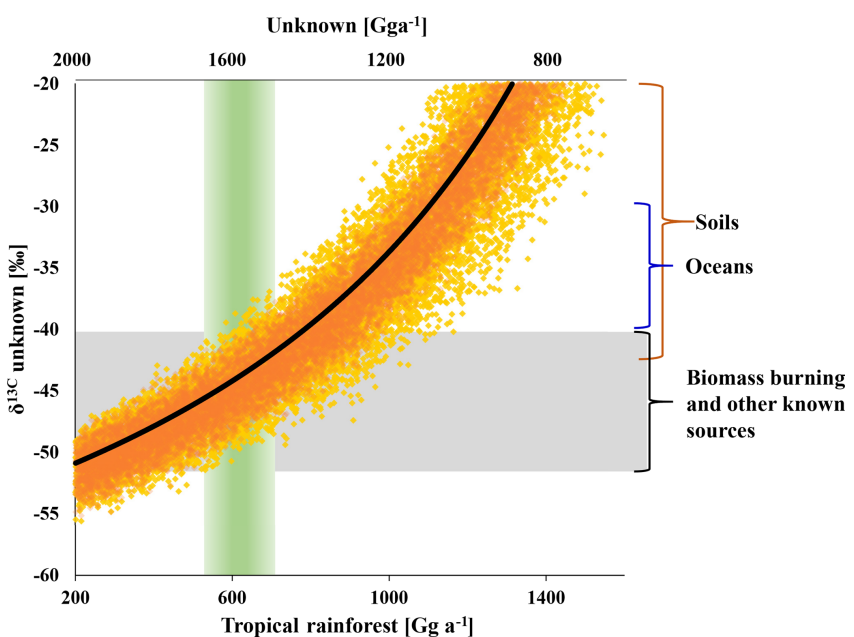

Figure 5. Modelled isotopic composition of the missing source versus tropical rainforest emissions on the lower $x$ axis and missing emissions on the upper $x$ axis (rainforest $=2200-$ unknown). The black line shows the best estimate derived from the mean isotopic source signatures. Orange dots indicate the range uncertainty $(1 \sigma)$ from uncertainties $(1 \sigma)$ in the $\delta^{13} \mathrm{C}$ of biomass burning $( \pm 7 \%$ ), ocean net emissions $( \pm 6 \%$ ) and other known sources $( \pm 6 \%$ ). Yellow dots mark the additional uncertainty from the $\delta^{13} \mathrm{C}$ of the tropical rainforest source $( \pm 10 \%)$. The green column indicates the carbon-density-based estimate of the rainforest source and the grey bar indicates the range in $\delta^{13} \mathrm{C}$ of biomass burning and the mean from all sources excluding the tropical rainforest.

boundary with which to constrain the rainforest source from an isotopic perspective.

\section{Carbon-density-based revision of the tropical rainforest source}

Interestingly, support for our lower estimate arises from previous studies on the tropical rainforest $\mathrm{CH}_{3} \mathrm{Cl}$ source when using above-ground carbon density instead of coverage area for upscaling the $\mathrm{CH}_{3} \mathrm{Cl}$ emission factors.

Large uncertainties in upscaling of locally derived plant emissions to global scales can arise from (i) temporal variations in the emissions and (ii) spatial variability in environmental drivers, species composition and vegetation cover. Within the widely used FAO land cover classes, forests are defined as land with tree cover exceeding $10 \%$, a potential tree height of $5 \mathrm{~m}$ and an area of at least 0.5 ha (FAO, 2012). Tropical rainforests encompass such sparsely covered areas with a carbon density of only a few $\mathrm{Mg} \mathrm{ha}^{-1}$ (Asner et al., 2010; Pereira et al., 2016) as well as very dense mature rainforests with a canopy height of more than $40 \mathrm{~m}$ and above-ground carbon densities sometimes exceeding $300 \mathrm{Mg} \mathrm{ha}^{-1}$ (Kato et al., 1978). This suggests a large variability in biomass that cannot be assessed with the previously used area-based upscaling approaches. Area-based es- 
timates may be improved by leaf area index or above-ground carbon-density-based approaches. There is some indication that $\mathrm{CH}_{3} \mathrm{Cl}$ is mainly emitted by mature trees (Saito and Yokouchi, 2008; Saito et al., 2008, 2013). This is more readily reflected by carbon density than by leaf area. Further, the available carbon density data products allow direct discrimination between tropical forests and other tropical vegetation. We thus propose a carbon-density-based upscaling approach of experimentally derived emission factors to reduce uncertainties arising from the spatial variability in above-ground biomass. We first convert reported area-based emission factors to carbon-density-based emission factors and then multiply them with the carbon stock of the tropical rainforest:

$F\left(\mathrm{CH}_{3} \mathrm{Cl}\right)=\frac{E_{F} \times C_{\mathrm{RF}}}{C_{\mathrm{st}}}$.

Here, $F\left(\mathrm{CH}_{3} \mathrm{Cl}\right)$ is the source strength $\left[\mathrm{Gg} \mathrm{a}^{-1}\right], E_{F}$ is the experimentally derived emission factor $\left[\mathrm{Gg} \mathrm{ha}^{-1} \mathrm{a}^{-1}\right], C_{\mathrm{st}}$ is the above-ground carbon density assigned to the sampling site $\left[\mathrm{Gg} \mathrm{ha}^{-1}\right]$ and $C_{\mathrm{RF}}$ is the estimated total above-ground biomass $[\mathrm{Gg}]$ of the respective biome, in this case the tropical rainforest.

The first direct evidence for strong $\mathrm{CH}_{3} \mathrm{Cl}$ emissions from tropical plants came from branch incubations of tropical plants in a greenhouse (Yokouchi et al., 2000). This study revealed particularly high emission from dipterocarp species that are dominant in tropical lowland rainforests of southern and south-eastern Asia and suggested mean $\mathrm{CH}_{3} \mathrm{Cl}$ emissions of $74 \mu \mathrm{g} \mathrm{m}^{2} \mathrm{~h}^{-1}$. Several follow-up studies carried out in tropical rainforests reported 10- to 5-fold lower fluxes (Saito et al., 2008, 2013; Gebhardt et al., 2008; Blei et al., 2010). We exclude the high-emission factor from the greenhouse study from our reanalysis of the tropical rainforest source and focus on the studies, providing experimentally derived emission factors for $\mathrm{CH}_{3} \mathrm{Cl}$ emissions from tropical forests and allowing for a sufficient estimate of carbon densities assignable to them. Details on these studies are provided in Table 5. Three studies have been carried out in lowland tropical rainforests of south-eastern Asia, and one has been carried out over Surinam in South America. We are not aware of any $\mathrm{CH}_{3} \mathrm{Cl}$ flux measurements from African tropical rainforests. Two studies relied on branch or leaf incubation to measure $\mathrm{CH}_{3} \mathrm{Cl}$ fluxes (Saito et al., 2013; Blei et al., 2010). A third study used a micrometeorological approach and in addition performed leaf and branch incubation (Saito et al., 2008). The remaining study (Gebhardt et al., 2008) derived $\mathrm{CH}_{3} \mathrm{Cl}$ emissions factors from concentration gradients above the rainforest. The concentration gradients were obtained from canister samples taken at different heights above the rainforest from an airplane. The results from branch and leaf incubations were first normalized to leaf dry weight and then converted to area-based emission factors using reported allometric data for south-eastern Asian tropical lowland rainforests along with assumptions of the distribution and abundance of the investigated species. The mean area normalized fluxes $\left(8.0 \mu \mathrm{g} \mathrm{m}^{2} \mathrm{~h}^{-1} \pm 45 \%\right)$ from these studies show a notably larger variability than the original leaf biomass normalized fluxes $\left(0.028 \mu \mathrm{g} \mathrm{g}^{-1} \mathrm{~h}^{-1} \pm 10 \%\right)$, although all three studies referred to the same allometric data (Yamakura et al., 1986) in their conversion. Note that the study reporting the lowest emissions factors from branch enclosures reported almost 3 times higher fluxes using a micrometeorological approach. In sum, the area-based factors agree within a factor of 3 and range from 5.0 to $14 \mu \mathrm{g} \mathrm{m}^{2} \mathrm{~h}^{-1}\left(9.1 \mu \mathrm{g} \mathrm{m}^{2} \mathrm{~h}^{-1} \pm 37 \%\right)$.

The three south-eastern Asian studies refer to a dense and mature dipterocarp forest with an above-ground carbon density of (265 \pm 44$) \mathrm{Mg} \mathrm{Cha}^{-1}$ (Yamakura et al., 1986) that we apply here. For the study carried out above the rainforest of Surinam, we derived a carbon density of $(160 \pm 15) \mathrm{Mg} \mathrm{ha}^{-1}$ from carbon density maps (Saatchi et al., 2011; Baccini et al., 2012).This range agrees with the FAO estimate for French Guyana (FAO, 2015) and is supported by several field surveys carried out in this region (Chave et al., 2001, 2008; Saatchi et al., 2007). With this, we obtain a mean carbondensity-based emission factor of (4.0 \pm 1.2$) \mathrm{g} \mathrm{Mg}^{-1}$, referring to a mean carbon density of $202 \mathrm{Mg} \mathrm{ha}^{-1}$. This is well above the average tropical rainforest carbon density, ranging from 96 to $117 \mathrm{Mg} \mathrm{ha}^{-1}$ (Baccini et al., 2012; Saatchi et al., 2011; Köhl et al., 2015; FAO, 2015).

In consequence, our carbon-density-based estimates of the tropical $\mathrm{CH}_{3} \mathrm{Cl}$ source are $30 \%$ to $70 \%$ lower than the respective area-based estimates (Table 6). The difference is in the range of $30 \%$ for dense old grown evergreen forests such as the Tierra Firme forests of French Guyana, between $40 \%$ and $50 \%$ for the moist tropical rainforest, and increases to almost $70 \%$ for the entire pantropical forests including dry tropical forests, degraded forests and plantations. This trend reflects the decreasing trend in carbon density in the tropical rainforest biomes as well as the effect of forest degradation. Regardless of the source for the carbon density estimates, our approach suggests a tropical rainforest $\mathrm{CH}_{3} \mathrm{Cl}$ source of $(670 \pm 250) \mathrm{Gg} \mathrm{a}^{-1}$, which is $53 \%$ to $65 \%$ lower than the respective area-based estimates in the range of 1200 to $2000 \mathrm{Gg} \mathrm{a}^{-1}$ (Saito et al., 2008, 2013; Gebhardt et al., 2008; Blei et al., 2010).

The uncertainty in the area-based emission factors is estimated to $24 \%$ from the standard deviation of the reported means. Additional uncertainties for our carbon-densitybased upscaling (compared to the previous area-based upscaling) arise from the uncertainties in the total above-ground carbon stocks $( \pm 8.6 \%)$ and the site-specific carbon density $( \pm 15 \%)$. Using error propagation, we estimate the total uncertainty of our approach to be $\pm 30.4 \%$. However, we note an urgent need for more detailed flux studies. Currently there is no information about how physiological and environmental drivers might affect $\mathrm{CH}_{3} \mathrm{Cl}$ emissions from tropical rainforests. Apart from the observation that some members of the Dipterocarpaceae family are particularly strong emitters of $\mathrm{CH}_{3} \mathrm{Cl}$, this also holds true with respect to species composition. 
Table 5. Calculation of carbon-density-based $\mathrm{CH}_{3} \mathrm{Cl}$ emission factors from previously reported area-based emission factors.

\begin{tabular}{|c|c|c|c|c|c|c|c|}
\hline \multirow[t]{3}{*}{ Site } & \multirow[t]{3}{*}{ Method } & \multirow[t]{3}{*}{ Carbon density } & \multicolumn{4}{|c|}{ Emission per } & \multirow[t]{3}{*}{ Reference } \\
\hline & & & \multirow{2}{*}{$\begin{array}{l}\text { leaf dry mass } \\
\qquad \mu \mathrm{gg}^{-1} \mathrm{~h}^{-1}\end{array}$} & \multicolumn{2}{|c|}{ area } & \multirow{2}{*}{$\begin{array}{l}\text { carbon density } \\
\mathrm{g} \mathrm{Mg}^{-1} \mathrm{a}^{-1}\end{array}$} & \\
\hline & & & & $\mu \mathrm{g} \mathrm{m}^{-2} \mathrm{~h}^{-1}$ & $\mathrm{gha}^{-2} \mathrm{a}^{-1}$ & & \\
\hline Glass house, Japan & branch enclosure & 325 & 0.32 & 74.0 & & & Yokouchi et al. (2000) \\
\hline Pasoh Forest Reserve, & micrometeorological & 265 & & 14.0 & 1226 & 4.6 & Saito et al. (2013) \\
\hline Malaysia & branch enclosure & & 0.03 & 5.0 & & & \\
\hline $\begin{array}{l}\text { Pasoh Forest Reserve, } \\
\text { Malaysia }\end{array}$ & branch enclosure & 265 & 0.026 & 7.0 & 615 & 2.3 & Saito et al. (2013) \\
\hline $\begin{array}{l}\text { Danum Valley, } \\
\text { Borneo, Malaysia }\end{array}$ & branch enclosure & 265 & 0.03 & 12.0 & 1051 & 4.0 & Blei et al. (2010) \\
\hline $\begin{array}{l}\text { Surinam, French } \\
\text { Guyana }\end{array}$ & gradient above canopy & 160 & & 9.5 & 832 & 5.2 & Gebhardt et al. (2008) \\
\hline Mean & & & & & 931 & 4.0 & \\
\hline SD & & & & & 265 & 1.2 & \\
\hline
\end{tabular}

Table 6. Comparison of calculated area-based and carbon-density-based emissions from tropical forests.

\begin{tabular}{lrrrrr}
\hline Region & $\begin{array}{r}\text { Area } \\
10^{6} \mathrm{ha}\end{array}$ & $\begin{array}{r}\mathrm{C} \text { density } \\
10^{6} \mathrm{~g} \mathrm{ha}^{-1}\end{array}$ & $\begin{array}{r}\text { Area-based } \\
\mathrm{Gg} \mathrm{a}^{-1}\end{array}$ & $\begin{array}{r}\text { Carbon-density-based } \\
\mathrm{Gg} \mathrm{a}^{-1}\end{array}$ & $\begin{array}{r}\text { Percentage of area } \\
\text { based }\end{array}$ \\
\hline Brazil & 586 & $112^{1}$ & $496 \pm 143$ & $247 \pm 73$ & 50 \\
Indonesia & 165 & $112^{1}$ & $140 \pm 40$ & $69 \pm 20$ & 50 \\
Congo & 205 & $92^{1}$ & $173 \pm 50$ & $71 \pm 21$ & 41 \\
Tropical Africa & 775 & $62^{1}$ & $655 \pm 189$ & $182 \pm 53$ & 28 \\
Tropical America & 1209 & $77^{1}$ & $1022 \pm 295$ & $356 \pm 103$ & 35 \\
Tropical Asia & 474 & $98^{1}$ & $401 \pm 116$ & $176 \pm 51$ & 44 \\
Pantropics & 2458 & $78^{1}$ & $2079 \pm 601$ & $720 \pm 212$ & 35 \\
\hline Tropical Africa & 393 & $82^{2}$ & $332 \pm 96$ & $121 \pm 36$ & 36 \\
Tropical America & 788 & $116^{2}$ & $666 \pm 192$ & $343 \pm 101$ & 52 \\
Tropical Asia & 289 & $119^{2}$ & $244 \pm 71$ & $580 \pm 171$ & 53 \\
Pantropics & 1470 & $105^{2}$ & $1243 \pm 359$ & & 47 \\
\hline
\end{tabular}

${ }^{1}$ Saatchi et al. (2011); ${ }^{2}$ Baccini et al. (2012).

\section{Conclusions}

We reported new $\varepsilon$ values for the reaction of $\mathrm{CH}_{3} \mathrm{Cl}$ with $\mathrm{OH}$ and $\mathrm{Cl}$ of $(-11.2 \pm 0.8) \% o(n=3)$ and $(-10.2 \pm 0.5) \%$, which are 5 to 7 times smaller than the previously reported $\varepsilon$ values for these reactions. Strong support for the reliability of our new fractionation factors arises from the absence of any significant covariation in the mixing and carbon isotope ratios of tropospheric $\mathrm{CH}_{3} \mathrm{Cl}$.

Conjoining our new KIEs of the tropospheric $\mathrm{CH}_{3} \mathrm{Cl}$ sinks and the biomass-based upscaling of previously reported emission factors suggests a tropical vegetation source of only $(670 \pm 200) \mathrm{Gg} \mathrm{a}^{-1}$, which is about 3 -fold smaller than suggested in current budgets. We assign $\delta^{13} \mathrm{C}$ of $-45 \pm 6 \%$ o to the missing emissions of $(1530 \pm 200) \mathrm{Gg} \mathrm{a}^{-1}$. Notably increasing the soil sink by $750 \mathrm{Gg} \mathrm{a}^{-1}$ and decreasing biomass burning emissions by $460 \mathrm{Gg} \mathrm{a}^{-1}$, as suggested in the latest assessment on ozone-depleting substances (Carpenter et al., 2014), would substantially increase this gap but have a negli- gible effect on the isotopic composition of the missing emissions. The $\delta^{13} \mathrm{C}$ value of the missing emissions matches with the mean source signature of the other known sources (except rainforests). Increasing these emissions within the given ranges might reduce the gap to $(1100 \pm 200) \mathrm{Gg} \mathrm{a}^{-1}$. From a purely isotopic perspective, in particular larger emissions from biomass burning could further reduce this gap. However, this is highly speculative as virtually any source combination providing a mean $\delta^{13} \mathrm{C}$ of $-45 \pm 6 \%$ could fill the gap.

With $\mathrm{CH}_{3} \mathrm{Cl}$ being the single largest natural carrier of chlorine to the stratosphere, predicting future baselines of stratospheric chlorine requires a better understanding of the global $\mathrm{CH}_{3} \mathrm{Cl}$ cycle and an identification of the missing emissions. 
Data availability. The data used in this publication and the model code are available to the community and can be accessed by request to the corresponding author.

Supplement. The supplement related to this article is available online at: https://doi.org/10.5194/acp-19-1703-2019-supplement.

Author contributions. EB, FK, JW, CZ, RS and HFS designed the experiment, EB, JW and CZ carried out the smog chamber experiments. MG carried out the isotope analysis in Heidelberg and EB carried out the isotope analysis in Hamburg. EB performed the modelling work. All authors contributed equally to the preparation of the manuscript.

Competing interests. The authors declare that they have no conflict of interest.

Acknowledgements. We acknowledge the German Federal Ministry of Education and Research (BMBF) for funding within SOPRAN "Surface Ocean Processes in the Anthropocene" (grants 03F0611E and 03F0662E). This study was further supported by DFG (KE 884/8-1; KE 884/8-2, KE 884/10-1) and by the DFG research unit "Natural Halogenation Processes in the Environment - Atmosphere and Soil" (KE 884/7-1, SCHO 286/7-2, ZE 792/5-2). We finally thank Simon O'Doherty, and Paul J. Fraser for the AGAGE data from Mace Head and Cape Grim. AGAGE is supported principally by NASA (USA) grants to MIT and SIO, DECC (UK) and NOAA (USA) grants to Bristol University, CSIRO and BoM (Australia), FOEN grants to EMPA (Switzerland), NILU (Norway), SNU (Korea), CMA (China), NIES (Japan) and Urbino University (Italy).

The publication of this article was funded by the Open Access Fund of the Leibniz Association.

Edited by: Jan Kaiser

Reviewed by: Matthew Johnson and Jochen Rudolph

\section{References}

Anderson, R. S., Huang, L., Iannone, R., Thompson, A. E., and Rudolph, J.: Carbon Kinetic Isotope Effects in the Gas Phase Reactions of Light Alkanes and Ethene with the $\mathrm{OH}$ Radical at $296 \pm 4 \mathrm{~K}$, J. Phys. Chem. A, 108, 11537-11544, https://doi.org/10.1021/jp0472008, 2004.

Anderson, R. S., Huang, L., Iannone, R., and Rudolph, J.: Measurements of the ${ }^{12} \mathrm{C} /{ }^{13} \mathrm{C}$ Kinetic Isotope Effects in the Gas-Phase Reactions of Light Alkanes with Chlorine Atoms, J. Phys. Chem. A, 111, 495-504, https://doi.org/10.1021/jp064634p, 2007.

Asner, G. P., Powell, G. V. N., Mascaro, J., Knapp, D. E., Clark, J. K., Jacobson, J., Kennedy-Bowdoin, T., Balaji, A., PaezAcosta, G., Victoria, E., Secada, L., Valqui, M., and Hughes, R. F.: High-resolution forest carbon stocks and emissions in the Amazon, P. Natl. Acad. Sci. USA, 107, 16738-16742, https://doi.org/10.1073/pnas.1004875107, 2010.

Baccini, A., Goetz, S. J., Walker, W. S., Laporte, N. T., Sun, M., Sulla-Menashe, D., Hackler, J., Beck, P. S. A., Dubayah, R., Friedl, M. A., Samanta, S., and Houghton, R. A.: Estimated carbon dioxide emissions from tropical deforestation improved by carbon-density maps, Nat. Clim. Change, 2, 182-185, https://doi.org/10.1038/nclimate1354, 2012.

Bahlmann, E., Weinberg, I., Seifert, R., Tubbesing, C., and Michaelis, W.: A high volume sampling system for isotope determination of volatile halocarbons and hydrocarbons, Atmos. Meas. Tech., 4, 2073-2086, https://doi.org/10.5194/amt-4-20732011, 2011.

Behnke, W., Holländer, W., Koch, W., Nolting, F., and Zetzsch, C.: A smog chamber for studies of the photochemical degradation of chemicals in the presence of aerosols, Atmos. Environ., 22, 1113-1120, 1988.

Blei, E., Hardacre, C. J., Mills, G. P., Heal, K. V., and Heal, M. R.: Identification and quantification of methyl halide sources in a lowland tropical rainforest, Atmos. Environ., 44, 1005-1010, https://doi.org/10.1016/j.atmosenv.2009.12.023, 2010.

Burkholder, J. B., Sander, S. P., Abbatt, J., Barker, J. R., Huie, R. E., Kolb, C. E., Kurylo, M. J., Orkin, V. L., Wilmouth, D. M., and Wine, P. H.: Chemical Kinetics and Photochemical Data for Use in Atmospheric Studies, Evaluation No. 18, JPL Publication 15-10, Jet Propulsion Laboratory, Pasadena, USA, 2015.

Butler, J. H.: Better budgets for methyl halides?, Nature, 403, 260261, https://doi.org/10.1038/35002232, 2000.

Buxmann, J., Balzer, N., Bleicher, S., Platt, U., and Zetzsch, C.: Observations of bromine explosions in smog chamber experiments above a model salt pan, Int. J. Chem. Kinet., 44, 312-326, 2012.

Cantrell, C. A., Shetter, R. E., McDaniel, A. H., Calvert, J. G., Davidson, J. A., Lowe, D. C., Tyler, S. C., Cicerone, R. J., and Greenberg, J. P.: Carbon kinetic isotope effect in the oxidation of methane by the hydroxyl radical, J. Geophys. Res.-Atmos., 95, 22455-22462, https://doi.org/10.1029/JD095iD13p22455, 1990.

Carpenter, L. J., Reimann, S., Burkholder, J. B., Clerbaux, C., Hall, B., Hossaini, R., Laube, J., and Yvon-Lewis, S.: Update on Ozone-Depleting Substances (ODSs) and Other Gases of Interest to the Montreal Protocol, chap. 1, in: Scientific Assessment of Ozone Depletion, Global Ozone Research and Monitoring Project Report, World Meteorological Organization (WMO), Geneva, Switzerland, 21-125, 2014.

Chave, J., Riéra, B., and Dubois, M.-A.: Estimation of biomass in a neotropical forest of French Guiana: spatial and temporal variability, J. Trop. Ecol., 17, 79-96, https://doi.org/10.1017/S0266467401001055, 2001.

Chave, J., Olivier, J., Bongers, F., Châtelet, P., Forget, P.-M., van der Meer, P., Norden, N., Riéra, B., and Charles-Dominique, P.: Above-ground biomass and productivity in a rain forest of eastern South America, J. Trop. Ecol., 24, 355-366, https://doi.org/10.1017/S0266467408005075, 2008.

Czapiewski, K. v., Czuba, E., Huang, L., Ernst, D., Norman, A. L., Koppmann, R., and Rudolph, J.: Isotopic Composition of Non-Methane Hydrocarbons in Emissions from Biomass Burning, J. Atmos. Chem., 43, 45-60, https://doi.org/10.1023/a:1016105030624, 2002. 
Danzer, K., Wagner, M., and Fischbacher, C.: Calibration by orthogonal and common least squares - Theoretical and practical aspects, Fresenius J. Anal. Chem., 352, 407-412, 1995

DeMore, W. B.: Rate constant ratio for the reactions of hydroxyl with methane-d and methane, J. Phys. Chem., 97, 8564-8566, https://doi.org/10.1021/j100135a006, 1993.

Elsner, M., Zwank, L., Hunkeler, D., and Schwarzenbach, R. P.: A New Concept Linking Observable Stable Isotope Fractionation to Transformation Pathways of Organic Pollutants, Environ. Sci. Technol., 39, 6896-6916, https://doi.org/10.1021/es0504587, 2005.

Farquhar, G., O'Leary, M., and Berry, J.: On the Relationship Between Carbon Isotope Discrimination and the Intercellular Carbon Dioxide Concentration in Leaves, Funct. Plant Biol., 9, 121137, https://doi.org/10.1071/PP9820121, 1982.

Feilberg, K. L., Griffith, D. W. T., Johnson, M. S., and Nielsen, C. J.: The ${ }^{13} \mathrm{C}$ and $\mathrm{D}$ kinetic isotope effects in the reaction of $\mathrm{CH}_{4}$ with $\mathrm{Cl}$, Int. J. Chem. Kinet., 37, 110-118, https://doi.org/10.1002/kin.20058, 2005.

Food and Agriculture Organization of the United Nations: Global Forest Resource Assessment 2012, Rome, Italy, ISBN 978-92-5107292-9, 2012.

Food and Agriculture Organization of the United Nations: Global Forest Resources Assessment 2015, Rome, Italy, Desk Reference, ISBN 978-92-5-108826-5, 2015.

Gebhardt, S., Colomb, A., Hofmann, R., Williams, J., and Lelieveld, J.: Halogenated organic species over the tropical South American rainforest, Atmos. Chem. Phys., 8, 3185-3197, https://doi.org/10.5194/acp-8-3185-2008, 2008.

Gola, A. A., D’Anna, B., Feilberg, K. L., Sellevåg, S. R., Bache-Andreassen, L., and Nielsen, C. J.: Kinetic isotope effects in the gas phase reactions of $\mathrm{OH}$ and $\mathrm{Cl}$ with $\mathrm{CH}_{3} \mathrm{Cl}$, $\mathrm{CD}_{3} \mathrm{Cl}$, and ${ }^{13} \mathrm{CH}_{3} \mathrm{Cl}$, Atmos. Chem. Phys., 5, 2395-2402, https://doi.org/10.5194/acp-5-2395-2005, 2005.

Greule, M., Huber, S. G., and Keppler, F.: Stable hydrogenisotope analysis of methyl chloride emitted from heated halophytic plants, Atmos. Environ., 62, 584-592, https://doi.org/10.1016/j.atmosenv.2012.09.007, 2013.

$\mathrm{Hu}$, L., Yvon-Lewis, S. A., Butler, J. H., Lobert, J. M., and King, D. B.: An improved oceanic budget for methyl chloride, J. Geophys. Res.-Oceans, 118, 715-725, https://doi.org/10.1029/2012JC008196, 2013.

Jalili, S. and Akhavan, M.: The study of isotope effects of chloroform and chloromethane using vibrational frequencies, J. Mol. Struct., 765, 105-114, https://doi.org/10.1016/j.theochem.2006.03.011, 2006.

Kaiser, J., Engel, A., Borchers, R., and Röckmann, T.: Probing stratospheric transport and chemistry with new balloon and aircraft observations of the meridional and vertical $\mathrm{N}_{2} \mathrm{O}$ isotope distribution, Atmos. Chem. Phys., 6, 3535-3556, https://doi.org/10.5194/acp-6-3535-2006, 2006.

Kato, R., Tadaki Y., and Ogawa, H.: Plant biomass and growth increment studies in Pasoh Forest, Malay. Nat. J., 30, 211-224, 1978.

Keppler, F., Harper, D. B., Röckmann, T., Moore, R. M., and Hamilton, J. T. G.: New insight into the atmospheric chloromethane budget gained using stable carbon isotope ratios, Atmos. Chem. Phys., 5, 2403-2411, https://doi.org/10.5194/acp-5-2403-2005, 2005.
Keppler, F., Bahlmann, E., Greule, M., Schöler, H. F., Wittmer, J., and Zetzsch, C.: Mass spectrometric measurement of hydrogen isotope fractionation for the reactions of chloromethane with $\mathrm{OH}$ and $\mathrm{Cl}$, Atmos. Chem. Phys., 18, 6625-6635, https://doi.org/10.5194/acp-18-6625-2018, 2018.

Köhl, M., Lasco, R., Cifuentes, M., Jonsson, Ö., Korhonen, K. T., Mundhenk, P., de Jesus Navar, J., and Stinson, G.: Changes in forest production, biomass and carbon: Results from the 2015 UN FAO Global Forest Resource Assessment, Forest Ecol. Manage., 352, 21-34, https://doi.org/10.1016/j.foreco.2015.05.036, 2015.

Komatsu, D. D., Tsunogai, U., Yamaguchi, J., Nakagawa, F., Yokouchi, Y., and Nojiri, Y.: The budget of atmospheric methyl chloride using stable carbon isotopic mass- balance, Poster A51C0784, AGU Fall Meeting, 13-17 December 2004, San Francisco, USA, 2004.

Lee-Taylor, J. M., Brasseur, G. P., and Yokouchi, Y.: A preliminary three-dimensional global model study of atmospheric methyl chloride distributions, J. Geophys. Res., 106, 34221-34233, 2001.

Merrigan, S. R., Le Gloahec, V. N., Smith, J. A., Barton, D. H. R., and Singleton, D. A.: Separation of the primary and secondary kinetic isotope effects at a reactive center using starting material reactivities. Application to the $\mathrm{FeCl}_{3}$-catalyzed oxidation of C-H bonds with tert-butyl hydroperoxide, Tetrahedron Lett., 40, 3847-3850, 1990.

Miller, L. G., Kalin, R. M., McCauley, S. E., Hamilton, J. T. G., Harper, D. B., Millet, D. B., Oremland, R. S., and Goldstein, A. H.: Large carbon isotope fractionation associated with oxidation of methyl halides by methylotrophic bacteria, P. Natl. Acad. Sci., 98, 5833-5837, https://doi.org/10.1073/pnas.101129798, 2001.

Miller, L. G., Warner, K. L., Baesman, S. M., Oremland, R. S., McDonald, I. R., Radajewski, J., and Colin Murell, J.: Degradation of methyl bromide and methyl chloride in soil microcosms: Use of stable $\mathrm{C}$ isotope fractionation and stable isotope probing to identify reactions and the responsible microorganisms, Geochim. Cosmochim. Ac., 68, 3271-3283, 2004.

Monzka, S. A., Reimann, S., Engel, A., Krüger, K., O’Doherty, S., Sturgres, W. T., Blake, D., Dorf, M., Fraser, P., Froidevaux, L., Jucks, K., Kreher, K., Kurylo, M. J., Mellouki, A., Miller, J., Nielsen, O.-J., Orkin, V. L., Prinn, R. G., Rhew, R., Santee, M. L., Stohl, A., and Verdonik, D.: Ozone-Depleting Substances (ODSs) and Other Gases of Interest to the Montreal Protocol, chap. 1, in: Scientific Assessment of Ozone Depletion, Global Ozone Research and Monitoring Project Report, World Meteorological Organization (WMO), Geneva, Switzerland, Report 52, 2010.

Morgan, C. G., Allen, M., Liang, M. C., Shia, R. L., Blake, G. A., and Yung, Y. L.: Isotopic fractionation of nitrous oxide in the stratosphere: Comparison between model and observations, J. Geophys. Res., 109, D04305, https://doi.org/10.1029/2003JD003402, 2004.

Penman, H. L.: Gas and vapour movements in the soil: I. The diffusion of vapours through porous solids, J. Agr. Sci., 30, 437-462, https://doi.org/10.1017/S0021859600048164, 1940.

Pereira Jr., L. R., de Andrade, E. M., Palácio, H. A. d. Q., Raymer, P. C. L., Filho, C. R., and Pereira, R. S.: Carbon stocks in a tropical dry forest in Brazil, Revista Ciência Agronômica, 47, 32-40 2016. 
Piansawan, T., Saccon, M., Vereecken, L., Gensch, I., and KiendlerScharr, A.: Temperature dependence of stable carbon kinetic isotope effect for the oxidation reaction of ethane by $\mathrm{OH}$ radicals: Experimental and theoretical studies, J. Geophys. Res.-Atmos., 122, 8310-8324, https://doi.org/10.1002/2017JD026950, 2017.

Prinn, R. G., Weiss, R. F., Fraser, P. J., Simmonds, P. G., Cunnold, D. M., Alyea, F. N., O’Doherty, S., Salameh, P., Miller, B. R., Huang, J., Wang, R. H. J., Hartley, D. E., Harth, C., Steele, L. P., Sturrock, G., Midgley, P. M., and McCulloch, A.: A history of chemically and radiatively important gases in air deduced from ALE/GAGE/AGAGE, J. Geophys. Res.-Atmos., 105, 1775117792, https://doi.org/10.1029/2000JD900141, 2000.

Redeker, K. R. and Kalin, R. M.: Methyl chloride isotopic signatures from Irish forest soils and a comparison between abiotic and biogenic methyl halide soil fluxes, Glob. Change Biol., 18, 1453-1467, https://doi.org/10.1111/j.1365-2486.2011.02600.x, 2012.

Redeker, K. R., Davis, S., and Kalin, R. M.: Isotope values of atmospheric halocarbons and hydrocarbons from Irish urban, rural, and marine locations, J. Geophys. Res.-Atmos., 112, D16307, https://doi.org/10.1029/2006JD007784, 2007.

Rudolph, J., Czuba, E., and Huang, L.: The stable carbon isotope fractionation for reactions of selected hydrocarbons with OH-radicals and its relevance for atmospheric chemistry, J. Geophys. Res.-Atmos., 105, 29329-29346, https://doi.org/10.1029/2000JD900447, 2000.

Saatchi, S. S., Houghton, R. A., Dos Santos Alvalá, R. C., Soares, J. V., and Yu, Y.: Distribution of aboveground live biomass in the Amazon basin, Glob. Change Biol., 13, 816-837, https://doi.org/10.1111/j.1365-2486.2007.01323.x, 2007.

Saatchi, S. S., Harris, N. L., Brown, S., Lefsky, M., Mitchard, E. T. A., Salas, W., Zutta, B. R., Buermann, W., Lewis, S. L., Hagen, S., Petrova, S., White, L., Silman, M., and Morel, A.: Benchmark map of forest carbon stocks in tropical regions across three continents, P. Natl. Acad. Sci. USA, 108, 98999904, https://doi.org/10.1073/pnas.1019576108, 2011.

Saito, T. and Yokouchi, Y.: Stable carbon isotope ratio of methyl chloride emitted from glasshouse-grown tropical plants and its implication for the global methyl chloride budget, Geophys. Res. Lett., 35, L08807, https://doi.org/10.1029/2007GL032736, 2008.

Saito, T., Yokouchi, Y., Kosugi, Y., Tani, M., Philip, E., and Okuda, T.: Methyl chloride and isoprene emissions from tropical rain forest in Southeast Asia, Geophys. Res. Lett., 35, L19812, https://doi.org/10.1029/2008GL035241, 2008.

Saito, T., Yokouchi, Y., Phillip, E., and Okuda, T.: Bidirectional exchange of methyl halides between tropical plants and the atmosphere, Geophys. Res. Lett., 40, 5300-5304, https://doi.org/10.1002/grl.50997, 2013.

Saltzman, E. S., Aydin, M., De Bruyn, W. J., King, D. B., and Yvon-Lewis, S. A.: Methyl bromide in preindustrial air: Measurements from an Antarctic ice core, J. Geophys. Res.-Atmos., 109, D05301, https://doi.org/10.1029/2003JD004157, 2004.

Sapart, C. J., Monteil, G., Prokopiou, M., van de Wal, R. S. W., Kaplan, J. O., Sperlich, P., Krumhardt, K. M., van der Veen, C., Houweling, S., Krol, M. C., Blunier, T., Sowers, T., Martinerie, P., Witrant, E., Dahl-Jensen, D., and Röckmann, T.: Natural and anthropogenic variations in methane sources during the past two millennia, Nature, 490, 85-88, https://doi.org/10.1038/nature11461, 2012.
Saueressig, G., Bergamaschi, P., Crowley, J. N., Fischer, H., and Harris, G. W.: Carbon kinetic isotope effect in the reaction of $\mathrm{CH}_{4}$ with $\mathrm{Cl}$ atoms, Geophys. Res. Lett., 22, 1225-1228, https://doi.org/10.1029/95GL00881, 1995.

Saueressig, G., Crowley, J. N., Bergamaschi, P., Brühl, C., Brenninkmeijer, C. A. M., and Fischer, H.: Carbon 13 and $\mathrm{D}$ kinetic isotope effects in the reactions of $\mathrm{CH}_{4}$ with $\mathrm{O}\left({ }^{1} \mathrm{D}\right)$ and $\mathrm{OH}$ : New laboratory measurements and their implications for the isotopic composition of stratospheric methane, J. Geophys. Res.-Atmos., 106, 23127-23138, https://doi.org/10.1029/2000JD000120, 2001.

Sellevåg, S. R., Nyman, G., and Nielsen, C. J.: Study of the Carbon13 and Deuterium Kinetic Isotope Effects in the $\mathrm{Cl}$ and $\mathrm{OH}$ Reactions of $\mathrm{CH}_{4}$ and $\mathrm{CH}_{3} \mathrm{Cl}$, J. Phys. Chem. A, 110, 141-152, https://doi.org/10.1021/jp0549778, 2006.

Shorter, J. H., Kolb, C. E., Crill, P. M., Kerwin, R. A., Talbot, R. W., Hines, M. E., and Harriss, R. C.: Rapid degradation of atmospheric methyl bromide in soils, Nature, 377, 717-719, https://doi.org/10.1038/377717a0, 1995.

Spivakovsky, C. M., Logan, J. A., Montzka, S. A., Balkanski, Y. J., Foreman-Fowler, M., Jones, D. B. A., Horowitz, L. W., Fusco, A. C., Brenninkmeijer, C. A. M., Prather, M. J., Wofsy, S. C., and McElroy, M. B.: Three-dimensional climatological distribution of tropospheric $\mathrm{OH}$ : Update and evaluation, J. Geophys. Res.-Atmos., 105, 8931-8980, https://doi.org/10.1029/1999JD901006, 2000.

Tans, P. P.: A note on isotopic ratios and the global atmospheric methane budget, Global Biogeochemical Cycles, 11, 77-81, https://doi.org/10.1029/96GB03940, 1997.

Thompson, A. E., Anderson, R. S., Rudolph, J., and Huang, L.: Stable carbon isotope signatures of background tropospheric chloromethane and CFC113, Biogeochemistry, 60, 191-211, https://doi.org/10.1023/a:1019820208377, 2002.

Trudinger, C. M., Etheridge, D. M., Sturrock, G. A., Fraser, P. J., Krummel, P. B., and McCulloch, A.: Atmospheric histories of halocarbons from analysis of Antarctic firn air: Methyl bromide, methyl chloride, chloroform, and dichloromethane, J. Geophys. Res.-Atmos., 109, D22310, https://doi.org/10.1029/2004JD004932, 2004.

Tsunogai, U., Yoshida, N., and Gamo, T.: Carbon isotopic compositions of C2-C5 hydrocarbons and methyl chloride in urban, coastal, and maritime atmospheres over the western North Pacific, J. Geophys. Res.-Atmos., 104, 16033-16039, https://doi.org/10.1029/1999JD900217, 1999.

Tyler, S. C., Ajie, H. O., Rice, A. L., Cicerone, R. J., and Tuazon, E. C.: Experimentally determined kinetic isotope effects in the reaction of $\mathrm{CH}_{4}$ with $\mathrm{Cl}$ : Implications for atmospheric $\mathrm{CH}_{4}$, Geophys. Res. Lett., 27, 1715-1718, https://doi.org/10.1029/1999GL011168, 2000.

Wanninkhof, R.: Relationship between wind speed and gas exchange over the ocean revisited, Limnol. Oceanogr.-Meth., 12, 351-362, https://doi.org/10.4319/lom.2014.12.351, 2014.

Weinberg, I., Bahlmann, E., Eckhardt, T., Michaelis, W., and Seifert, R.: A halocarbon survey from a seagrass dominated subtropical lagoon, Ria Formosa (Portugal): flux pattern and isotopic composition, Biogeosciences, 12, 1697-1711, https://doi.org/10.5194/bg-12-1697-2015, 2015.

Wittmer, J., Bleicher, S., and Zetzsch, C.: Iron(III)-Induced Activation of Chloride and Bromide from Modeled Salt Pans, J. Phys. 
Chem. A, 119, 4373-4385, https://doi.org/10.1021/jp508006s, 2015.

Xiao, X., Prinn, R. G., Fraser, P. J., Weiss, R. F., Simmonds, P. G., O'Doherty, S., Miller, B. R., Salameh, P. K., Harth, C. M., Krummel, P. B., Golombek, A., Porter, L. W., Butler, J. H., Elkins, J. W., Dutton, G. S., Hall, B. D., Steele, L. P., Wang, R. H. J., and Cunnold, D. M.: Atmospheric three-dimensional inverse modeling of regional industrial emissions and global oceanic uptake of carbon tetrachloride, Atmos. Chem. Phys., 10, 10421-10434, https://doi.org/10.5194/acp-10-10421-2010, 2010.

Yamakura, T., Hagihara, A., Sukardjo, S., and Ogawa, H.: Aboveground biomass of tropical rain forest stands in Indonesian Borneo, Vegetatio, 68, 71-82, available at: https://link.springer. com/article/10.1007/BF00045057 (last access: 4 February 2019), 1986.

Yokouchi, Y., Noijiri, Y., Barrie, L. A., Toom-Sauntry, D., Machida, T., Inuzuka, Y., Akimoto, H., Li, H. J., Fujinuma, Y., and Aoki, S.: A strong source of methyl chloride to the atmosphere from tropical coastal land, Nature, 403, 295-298, https://doi.org/10.1038/35002049, 2000.
Yokouchi, Y., Ikeda, M., Inuzuka, Y., and Yukawa, T.: Strong emission of methyl chloride from tropical plants, Nature, 416, 163$165,2002$.

Yoshida, Y., Wang, Y., Shim, C., Cunnold, D., Blake, D. R., and Dutton, G. S.: Inverse modeling of the global methyl chloride sources, J. Geophys. Res.-Atmos., 111, D16307, https://doi.org/10.1029/2005JD006696, 2006.

Zhang, L., Brook, J. R., and Vet, R.: A revised parameterization for gaseous dry deposition in air-quality models, Atmos. Chem. Phys., 3, 2067-2082, https://doi.org/10.5194/acp-3-2067-2003, 2003. 